\title{
Review \\ Comprehensive Overview of Gene Rearrangements in Childhood T-Cell Acute Lymphoblastic Leukaemia
}

\author{
Anna Mroczek ${ }^{1}$, Joanna Zawitkowska ${ }^{1}$, Jerzy Kowalczyk ${ }^{1}$ and Monika Lejman ${ }^{2, *(D)}$ \\ 1 Department of Paediatric Haematology, Oncology and Transplantology, Medical University of Lublin, \\ 20-093 Lublin, Poland; anna.mroczek94@wp.pl (A.M.); jzawitkowska1971@gmail.com (J.Z.); \\ jerzy.kowalczyk@uszd.lublin.pl (J.K.) \\ 2 Laboratory of Genetic Diagnostics, Medical University of Lublin, 20-093 Lublin, Poland \\ * Correspondence: monika.lejman@umlub.pl or lejmanm@poczta.onet.pl; Tel.: +48-609-095-533
}

Citation: Mroczek, A.; Zawitkowska,

J.; Kowalczyk, J.; Lejman, M.

Comprehensive Overview of Gene Rearrangements in Childhood T-Cell Acute Lymphoblastic Leukaemia. Int. J. Mol. Sci. 2021, 22, 808. https:// doi.org/10.3390/ijms22020808

Received: 22 December 2020 Accepted: 12 January 2021 Published: 15 January 2021

Publisher's Note: MDPI stays neutral with regard to jurisdictional clai$\mathrm{ms}$ in published maps and institutional affiliations.

Copyright: $(\odot 2021$ by the authors. Licensee MDPI, Basel, Switzerland. This article is an open access article distributed under the terms and conditions of the Creative Commons Attribution (CC BY) license (https:// creativecommons.org/licenses/by/ $4.0 /)$.

\begin{abstract}
Acute lymphoblastic leukaemia (ALL) is a relevant form of childhood neoplasm, as it accounts for over $80 \%$ of all leukaemia cases. T-cell ALL constitutes a genetically heterogeneous cancer derived from T-lymphoid progenitors. The diagnosis of T-ALL is based on morphologic, immunophenotypic, cytogenetic, and molecular features, thus the results are used for patient stratification. Due to the expression of surface and intracellular antigens, several subtypes of T-ALL can be distinguished. Although the aetiology of T-ALL remains unclear, a wide spectrum of rearrangements and mutations affecting crucial signalling pathways has been described so far. Due to intensive chemotherapy regimens and supportive care, overall cure rates of more than $80 \%$ in paediatric T-ALL patients have been accomplished. However, improved knowledge of the mechanisms of relapse, drug resistance, and determination of risk factors are crucial for patients in the high-risk group. Even though some residual disease studies have allowed the optimization of therapy, the identification of novel diagnostic and prognostic markers is required to individualize therapy. The following review summarizes our current knowledge about genetic abnormalities in paediatric patients with T-ALL. As molecular biology techniques provide insights into the biology of cancer, our study focuses on new potential therapeutic targets and predictive factors which may improve the outcome of young patients with T-ALL.
\end{abstract}

Keywords: T-ALL; genomic landscape; paediatrics

\section{Introduction}

Acute lymphoblastic leukaemia (ALL) is the most frequent neoplasm in paediatric patients. Among ALL cases in children, $15 \%$ represent diseases derived from T cells, and the remaining $\sim 85 \%$ consist of B cell precursor (BCP)-ALL [1-3]. The ALL subtypes occur among adults with a frequency of $\sim 25$ and $\sim 75 \%$, respectively [1,3-5]. Due to the expression of surface and intracellular antigens, we distinguish several subtypes of TALL. The European Group for Immunologic Classification (EGIL) scale is used to classify T-ALL into subtypes. EGIL T-I corresponds to pro-T (characterized by cCD3+, CD7+); EGIL T-II is pre-T (cCD3+, CD7+, CD5/CD2+); EGIL T-III is cortical-T (cCD3+, Cd1a+, sCD3+/-); and EGIL T-IV corresponds to mature-T (cCD3+, sCD3+, CD1a-) and T- $\gamma / \delta$, with observed frequencies of 5.1,31.4, 38.1, 15.3, and 10.2\% respectively [2,6-8]. However, this classification does not inform us about the prognostic value of individual groups.

The development of medicine and the modification of therapeutic protocols lead to increasingly improved results in ALL paediatric patients in terms of total remission and long-term survival. The 5-year survival rate for ALL patients under 20 years of age has improved significantly over time and is currently $90 \%$ [9]. However, there is still a group of patients who do not achieve such results $[3,10]$. According to reports, every fifth child suffering from T-ALL experiences a relapse or dies due to this disease [11-13]. The main cause of death of patients with ALL is relapse [11,14]. Relapse is a result of the 
proliferation of the most resistant cells that survive after previous treatment. Therefore, therapy for relapse is limited due to the observed drug resistance and shows poorer results compared to the treatment of the primary disease $[15,16]$. Moreover, marked intensification of therapy among young patients will not resolve the problem because of reduced tolerance to cytotoxic substances and severe side effects [3,10-12]. Therefore, alternative forms of therapy are required. It is necessary to optimize the treatment based on patient classification using molecular genetic markers and individual genetic profiles [2,12,17,18].

In recent years, a subgroup of early T-cell precursor (ETP)-ALL has been identified among patients, which is characterized by worse prognosis and chemoresistance in comparison to non-ETP-ALL [1]. ETP is derived from thymocytes, which are capable of differentiating into $\mathrm{T}$ cells and marrow cells, which proves their hematopoietic nature $[19,20]$. In paediatric T-ALL/acute lymphoblastic lymphoma (LBL), the ETP-ALL subgroup represents $11-13 \%$ cases, while in adults it constitutes $7.4 \%$, but some studies indicate that ETP-ALL occurs in 15 and 10-30\%, respectively [2,20-23]. Patients with ETP-ALL are significantly older at diagnosis, have a higher percentage of blasts in the marrow or peripheral blood, and circulating white blood cell (WBC) counts less than $50 \times 109 / \mathrm{L}$ in comparison to patients with non-ETP-ALL [24]. Immunophenotypic screening criteria are used to diagnose ETP-ALL. ETP-ALL is characterized by the absence of both CD1a and CD8 (absent in more than 95\% of leukemic cells), the absence or weak expression of CD5 (in $\leq 75 \%$ of total cells or 10 times less than in normal $\mathrm{T}$ cells), or the expression of at least one stem cell marker/stem cell: CD117, CD34, HLA-DR, CD13, CD33, CD11b, or CD65 (equal or more than $25 \%$ of total cells) [23]. In terms of immunophenotype, chromosomal aberrations, and genetic mutations, ETP-ALL is more similar to a myeloid malignancy, therefore there may be a need to separate this group from all T-ALL cases in order to apply another targeted treatment $[25,26]$.

Despite immunophenotypic heterogeneity and interchangeability, T-ALL is associated with significant genetic heterogeneity. Leukemic transformation occurs through the accumulation of numerous genetic and epigenetic abnormalities [27]. They cause disorders of cell differentiation, apoptosis, activation of oncogenes, and inhibition of suppressors, as a result of excessive neoplastic cell proliferation. Chromosome aberrations were the first genetic changes observed in T-ALL patients, occurring in half of them [9]. Kowalczyk et al. in 1983 were the first to discover the genetic instability of chromosome 9p in patients diagnosed with T-ALL and suggested that it might correlate with poorer outcomes and reduced time of survival [28]. Intensified research in this field showed that of the genes located on the 9p21 deletion and promoter, hypermethylation of CDKN2A and CDKN2B genes has been observed in more than $70 \%$ of T-ALL patients. Through the use of advanced genome sequencing technology, mutations associated with the process of leukemogenesis by silencing cell cycle inhibitors and tumour suppressor genes were described. In both paediatric and adult patients with T-ALL, the most frequent gene mutation observed in $60 \%$ of cases was the NOTCH1, lying on the long arm of chromosome 9 . The next most commonly reported gene alterations in ALL derived from T cell patients were FBXW7 (8-30\%), PHF6 (20\%), PTEN (20\%), WT1 (15\%), RUNX1 (10-20\%), LEF1 (10-15\%), and ETV6 (5-15\%). As mentioned earlier, ETP-ALL shows some molecular and genetic similarity to myeloid malignancies. In ETP-ALL, mutations in DNMT3A, ETV6, FLT3, GATA3, IDH1, $I D H 2, J A K 3, N R A S / K R A S$, and RUNX1 genes have been seen with greater frequency in comparison to non-ETP-ALL cases [17].

There is considerably more information about genetic abnormalities in acute lymphoblastic leukaemia from B cells compared to T-ALL. Due to its rare occurrence and high heterogeneity compared to $\mathrm{BCP}-\mathrm{ALL}$, the predictive factors and diagnostic markers of T-ALL are not well established. No genetic prognostic factor has been found for T-ALL so far. Therefore, T-ALL is the subject of intensive research among scientists [18]. In this review, we focus on a summary of knowledge about genetic alterations in T-ALL patients and their correlation with treatment response and prognosis, as well as the possibility to use them as points for prospective targeted therapies. 


\section{Genetic Profile of T-ALL}

\subsection{Transcription Factor}

Chromosome aberrations were the first genetic changes observed in patients with T-ALL, and they occur in half of patients. It is supposed that chromosome aberrations initiate the process of carcinogenesis, but without accompanying copy number alterations (CNAs) they are not responsible for the formation of leukemic cells.

Oncogenic transcription factors can be divided into several groups: TAL, LMO1/2, TLX1/3, LYL, HOXA, MEF2C, NKX1, and NKX2. Aberrant expression of these factors is an element of T-ALL molecular pathogenesis (Table 1). Abnormal expression of specific transcription factors allow division of T-ALL patients into molecular subgroups [9,29-31]. Rearrangements involving the $\mathrm{T}$ lymphocyte receptor ( $\mathrm{T}$ cell antigen receptor, TCR) are common changes in T-ALL and affect from $35 \%$ to almost half of patients [32,33]. With this in mind, T-ALL patients were divided into subgroups. The most common subtype emerging from mature late cortical thymocytes (CD4+ CD8+, CD3+) was characterized by TAL1 with coexisting $L M O 1 / 2$, affecting 30 to $37.5 \%$ of patients $[29,33]$. The second most frequent subtype (20-25\%) had HOXA-t, CALM-AF10, and KMT2A-rearrangements (KMT2A-R). In the next subtype, with a frequency of 20-24\%, abnormal expression of TLX3 was observed. Additionally, it was observed that this group was characterized by more frequent loss of function of other genes due to mutations. Of T-ALL patients, $3-8 \%$ had aberrant expression of TLX1. The least numerous groups, representing 5.9 and $2.5 \%$, were characterized by NKX-1.-2 and MEF2C, respectively [29]. CD1a+, CD4+, CD8+ immunophenotype cells had complete ectopic expression of TLX1, TLX3, or NKX-1.-2, and ETP-ALL patients had abnormal expression of transcription factors LMO2/LYL1 [33].

As many as one in three patients with diagnosed T-ALL have chromosomal translocations present in tumour cells $\mathrm{t}(10 ; 14)(\mathrm{q} 24 ; \mathrm{q} 11)$ or through $\mathrm{t}(7 ; 10)(\mathrm{q} 35 ; \mathrm{q} 24)$, leading to abnormal HOX11 (TLX1) activation. The high expression level of this gene was observed in $19.7 \%$ of patients, while low values were observed in $28.9 \%$. Comparing the treatment results, both groups achieved similar outcomes. However, the analysis of samples of healthy patients did not show the presence of HOX11 expression [34].

KMT2A are highly pathogenic leukemic drivers, revealed by the high incidence of KMT2A-rearangements in ALL in infants, with few cooperative mutations associated with leukaemia [1]. Rearrangement of the KMT2A (formerly MLL; 11q23) gene has been observed more frequently in paediatric patients with T-ALL than BCP-ALL, with a frequency of $4-8 \%[35,36]$. Histone-lysine N-methyltransferase 2A is responsible for controlling the genes involved in the haematopoiesis process. More than 135 partner genes that merge with $K M T 2 A$ have been described in recent papers. In a study conducted by Peterson et al., KMT2A was most often accompanied by partner genes such as MLLT1 (19p13.3), AFDN (formerly AF6-6q27), ELL (19p13.11), and MLLT10 (10p12.31). These were observed in respectively $33,30,7$, and $4 \%$ of T-ALL patients aged 1-20 years. Interestingly, none of the patients had KMT2A fusions with AFF1 (4q21) and MLLT3 (9p21.3) genes, which is more characteristic of AML and BCP-ALL. It is worth noting that mergers with KMT2A tend to have a poor prognosis, but of all gene partners, MLLT1 has a better prognosis in T-ALL/LBL [36].

Mansur et al. suggested that KMT2A rearrangements and NOTCH1 mutations may be the first changes responsible for the process of T-ALL in infants. Fifteen patients under 2 years of age with T-ALL were studied. It was observed that the most common alterations in this group were NOTCH1 mutations and KMT2A-R, which often involved partner genes: MLLT1 and AFF1 [37]. In research carried out by Matlawska-Wasowska, $12 \%$ of patients had KMT2A-related rearrangements. The most common partner genes were MLLT4 (every third patient), del3'KMT2A (25\%), MLLT1 (25\%), and MLLT6-17q12 (8.3\%) [38]. ALL patients with $K M T 2 A-R$ are at high risk and represent a major therapeutic challenge. Only in less than $60 \%$ of cases is long-term survival achieved. Infants are a special age group, characterized by a severe course and increased risk of relapse [39]. To summarize, KMT2A-R occurs in paediatric patients with T-ALL at a frequency of $4-12 \%$, often involving the MLLT4 and 
MLLT1 partner gene. KMT2A-R could play an important role in leukaemia development and may be related to poor prognosis [40].

Abnormalities in the protooncogene group of MYB (6q23) and MYC (8q24) genes were observed in patients with paediatric T-ALL. In a study conducted by Liu, alteration of $M Y B$ was found in $18.6 \%$ of cases. Of these, $12.5 \%$ were amplified, $4.92 \%$ mutated, and $4.17 \%$ rearranged. TCRB and $S L C 12 A 9$ are the partner genes that are merged with the $5^{\prime}$ region of $M Y B$, whereas the $M Y B-\mathrm{R} 3^{\prime}$ region in involved PLAGL1, BDP1, and CHMP1A partner genes [41]. Lejman et al. observed the coexistence of CNAs in MYB and AIH1 (2q34) in $12.94 \%$ of paediatric patients with T-ALL, but these lesions were not observed separately [42]. Thakral et al. conducted research on 27 childhood and adult T-ALL patients and monitored MYB disorders with a similar frequency of 11\% [43]. Translocation between chromosomes 6 and 7 was another way to activate the above-described gene [41]. MYC gene translocation was described in $6.1 \%$ of patients. This disorder occurred at a similar frequency in children and adults with T-ALL. In T-ALL, MYC translocations can be caused by chromosome 6 and 7 trisomy [44]. Excessive expression of MYC may also be due to gain-of-function NOTCH1 mutations [45]. It is worth mentioning that changes in the PI3K/AKT path often leads to increased expression of MYC [46]. In patients with abnormal MYC, some genetic abnormalities were found with higher frequency than in other patients. CDKN2A/B deletions occurred in three-quarters of patients and PTEN deletion or mutation was observed in more than half. Studies on mouse models have shown that elevated expression of C-MYC closely correlates with T-ALL development, and its inhibition prevents T-ALL [44].

Mutations in the RUNX1 (21q22.12) gene have been identified in $12.7 \%$ of patients. The role of this gene is assigned in early haematopoiesis. RUNX1 abnormalities are dominant in patients with early T-ALL. Shorter overall survival (OS) was observed in patients in whom RUNX1 mutations were accompanied by CDKN2A hypermethylation; however, due to too few patients, this result was not statistically significant. On the other hand, the coexistence of RUNX1 mutation with mutations in GATA3 and SH2B3 genes led to a worse result in patients [17].

The $B C L 11 B$ (14q32.2) gene is a regulator of $\mathrm{T}$ cell line differentiation and takes part in the conversion of cell precursors to mature T cells. 14q32.2of the BCL11B gene occurred in $2 \%$ of examined children. Moreover, this mutation was reported in as many as $16 \%$ of patients with TLX1 overexpression [47]. In a study evaluated by Gutierrez et al., BCL11B gene mutation and deletion were found in 9\% [48]. Its role in T-ALL development has not been defined yet [47].

The ETV6 (12q13.2) gene takes part in haematopoiesis by influencing cell proliferation and differentiation. Deletion of ETV6 was observed in 2 out of $36(5.6 \%)$ paediatric patients with T-ALL [49]. The loss of heterozygosity of this gene was observed with a frequency of $6 \%$ in patients with T-ALL [50]. ETV6/RUNX1 $\mathrm{t}(12 ; 21)(\mathrm{p} 13 ; \mathrm{q} 22)$, which often co-occurs with deletion of the ETV6 gene, is a typical rearrangement in childhood BCP-ALL, while in T-ALL, fusion-related signalling pathway or transcriptional regulation (ETV6/ABL1 and ETV6/CTNNB1) was observed [41].

GATA3 (10p14) belongs to the family of transcription factors and is involved in haematopoiesis. GATA3 expression is key in transforming common lymphocyte progenitors into $\mathrm{T}$ lymphocytes and in differentiating Th2 effector cells [51]. Inactivating mutations of this gene have been reported in $9 \%$ of paediatric patients with ETP-ALL, representing about $10-15 \%$ of all T-ALL cases [52]. Analysis suggested that the signal transducer and activator of transcription (STAT)/Janus kinase (JAK) pathway activation in the GATA3 regulatory network is a reliable mechanism for combining high expression of GATA3 with ALL and therapy response. In a study conducted on peripheral T-cell lymphoma, GATA3 overexpression was linked with poor OS [53].

LEF1 (4q25) is a nuclear protein that is expressed in pre-B and -T cells and binds to a functionally important site in the $\mathrm{T}$ cell receptor alpha (TCRA) enhancer, and confers maximal enhancer activity [54]. In order to determine the significance of LEF1 in the patho- 
genesis of T-ALL in children, Gutierrez et al. conducted a study involving 47 paediatric patients with diagnosed T-ALL. A biallelic or monoallelic deletion of tumour suppressor gene $L E F 1$ was noticed in $11 \%$ of them. Moreover, nonsynonymous sequence alterations of LEF1 were detected with a frequency of 7\% [55]. In another study, this CNA occurred in $10-24.5 \%$ of children and adult T-ALL cases [17]. Thakral et al. reported LEF1 alterations in 7.4\% $(n=2)$ T-ALL patients [43]. Additionally, LEF1 was most commonly observed in the NKX2-1 T-ALL group [41]. Patients with LEF1 inactivation were characterized by young age, thymocyte immunophenotype (CD1B+, CD1E+, CD8+, CD34-), increased expression of $M Y C$ and activation mutations of NOTCH1, PI3K, and AKT, PTEN inactivation mutations, and total inactivation of INK4A/ARF [55]. Opinions are divided on the role of LEF1 inactivation in T-ALL. Montaño demonstrated that LEF1 inactivation correlates with better OS in children and better response to salvage treatment [56]. In contrast, in a study conducted by Yeh et al., worse OS and a higher risk of relapse in LEF1 deletion group of patients were observed [57].

WT1 (11p13) gene encodes a zinc finger DNA-binding protein that acts as a transcriptional activator or repressor depending on the cellular or chromosomal context. WT1 occurred in $13.2 \%$ of children with diagnosed T-ALL, $84 \%$ of which was heterozygous. The mutation most often concerned the C-terminal zinc finger fragment [58]. Liu et al. observed WT1 in $9.1 \%$ of paediatric T-ALL patients [41]. A relationship between the occurrence of WT1 mutation and abnormal expression of specific transcription factors TLX1 (HOX11), TLX3 (HOX11L2), and HOXA9 was observed. This study excluded the association of WT1 mutation with poor prognosis of patients. No differences in treatment response were observed. Five-year OS was similar in both groups: $60 \pm 21 \%$ for the group with WT1 mutation and $70 \pm 8 \%$ for the group without [58].

NF1 (17q11.2) gene encodes neurofibromin, a cytoplasmic protein that is predominantly expressed in leukocytes, among other cells. NF1 regulates several intracellular processes, including the RAS-cyclic AMP pathway, the MAP kinase cascade, adenylyl cyclase, and cytoskeletal assembly [59]. Thakral et al., in a study involving a small cohort of patients, observed deletion of NF1 and SUZ12 (17q11.2) at 7.4\% each. The loss of this gene function was related to poor prognosis and failure of treatment induction [43]. Yeh et al. did not report any case of NF1 or SUZ12 deletion [57]. SUZ12 is a component of polycomb group complexes (PRCs) 2,3, and 4, which are critical for proper embryonic development [60].

IKAROS family members are involved in the process of haematopoiesis by regulating lymphocyte differentiation [61]. The loss of function of the IKZF1 (7p12.2) gene as a result of deletion or mutation can lead to the development of T-ALL, because this gene encodes the IKAROS protein, which acts as a suppressor [62]. In a study carried out on 27 paediatric and adult T-ALL patients, Thakral et al. recorded a loss of IKZF1 at $7.4 \%$ [43]. Deletion and mutation of IKZF1 were observed in 2.8 and $2 \%$ of T-ALL cases, respectively $[49,63]$. Krzanowski et al. conducted a study examining IKZF1 gene deletion in 24 children with T-ALL and 66 with BCP-ALL. He observed that patients with T-ALL were characterized by a lower incidence of $R B 1$ deletion compared to BCP-ALL (10.53 and $40.63 \%$, respectively) [64]. It was suggested that the loss of IKZF1 is related to poor outcome, especially in BCP-ALL patients [41]. The IKZF2 gene (2q34) belongs to the IKAROS family and encodes the synthesis of zinc finger protein Helios, which is necessary for proper lymphocyte differentiation and which is assigned probable importance as a cancer development suppressor. Interestingly, an IKZF2 gene microdeletion was observed in 3.4\% T-ALL childhood cases [63]. 
Table 1. Transcription factors in T-ALL (T-cell acute lymphoblastic leukaemia).

\begin{tabular}{|c|c|c|c|c|c|c|}
\hline Gene & Locus & Alterations & Partners gene & Incidence & Relevance & References \\
\hline \multirow[t]{2}{*}{$\begin{array}{c}\text { TAL1 } \\
(S C L, T C L 5)\end{array}$} & \multirow[t]{2}{*}{$1 \mathrm{p} 32$} & $\begin{array}{c}\text { Overexpression } \\
\text { with coexisting } \\
L M O 1 / 2\end{array}$ & STIL (1p33) & $30-37.5 \%$ & \multirow{2}{*}{$\begin{array}{c}\text { Adverse, } \\
\text { potential MRD } \\
\text { marker }\end{array}$} & {$[29,33]$} \\
\hline & & deletions & - & $7.7-25 \%$ & & [65-67] \\
\hline $\begin{array}{c}\text { TLX3 } \\
(\text { HOX11L2) }\end{array}$ & $5 q 35$ & Overexpression & BCL11B (14q32) & $20-24 \%$ & Adverse & [29] \\
\hline \multirow[b]{2}{*}{ TLX1 (HOX11) } & \multirow[b]{2}{*}{$10 \mathrm{q} 24$} & & TCRD (14q11) & $3-8 \%$ & Favorable & \multirow[b]{2}{*}[29,34]{} \\
\hline & & $\begin{array}{l}\text { Expression } \\
\text { level }\end{array}$ & $T C R B(7 q 35)$ & $\begin{array}{l}\mathrm{OE}^{1} 19.7 \% \\
\mathrm{LE}^{2} 28.9 \%\end{array}$ & $\mathrm{~N} / \mathrm{A}^{3}$ & \\
\hline $\begin{array}{l}\text { NKX2-1 } \\
N K X 2-2\end{array}$ & $\begin{array}{l}14 q 13 \\
20 p 11\end{array}$ & Overexpression & - & $5.9 \%$ & Unidentified & [29] \\
\hline $\begin{array}{l}\text { LMO1 } \\
\text { (TTG1) }\end{array}$ & $11 \mathrm{p} 15$ & Translocations & $\begin{array}{c}\text { TRB (7q34) } \\
\text { TRA (14q11.2) } \\
\text { TRD (14q11) }\end{array}$ & $<1 \%$ & Unidentified & [41] \\
\hline \multirow[t]{2}{*}{$\begin{array}{l}\text { LMO2 } \\
\text { (TTG2) }\end{array}$} & \multirow[t]{2}{*}{$11 \mathrm{p} 13$} & Translocations & $\begin{array}{l}\text { TRA (14q11.2) } \\
\text { FOXJ3 (1p34) }\end{array}$ & \multirow[t]{2}{*}{$\begin{array}{c}7.7 \% \\
5 \%\end{array}$} & \multirow[t]{2}{*}{ Unidentified } & \multirow[t]{2}{*}[41]{} \\
\hline & & Deletions & $\operatorname{del}(1)(\mathrm{p} 12 \mathrm{p} 13)$ & & & \\
\hline$M E F 2 C$ & $5 q 14.3$ & Overexpression & $\begin{array}{l}\text { CLINT1 } \\
(5 q 33.3)\end{array}$ & $2.5 \%$ & $\begin{array}{l}\text { Adverse, } \\
\text { reduce response } \\
\text { to steroids }\end{array}$ & {$[13,29]$} \\
\hline $\begin{array}{l}\text { BCL11B } \\
\text { (CTIP2) }\end{array}$ & $14 \mathrm{q} 32.2$ & Mutations & - & $2-9 \%$ & Unidentified & {$[47,48]$} \\
\hline $\begin{array}{c}\text { KMT2A } \\
(M L L)\end{array}$ & $11 q 23$ & Rearrangements & $\begin{array}{c}\text { Various } \\
\text { partners gene }\end{array}$ & $4-12 \%$ & Adverse & {$[35-40]$} \\
\hline \multirow[t]{3}{*}{$M Y B$} & \multirow[t]{3}{*}{$6 q 23$} & Rearrangements & $\begin{array}{c}\text { TCRB (7q34) } \\
\text { SLC12A9 (7q22) } \\
\text { PLAGL1 (6q24) } \\
\text { BDP1 (95q13) } \\
\text { CHMP1A } \\
(16 \mathrm{q} 24)\end{array}$ & $4.17 \%$ & \multirow[t]{3}{*}{ Unidentified } & [41] \\
\hline & & Mutations & - & $4.92 \%$ & & [41] \\
\hline & & Amplifications & - & $12.5-12.94 \%$ & & {$[41,42]$} \\
\hline$M Y C$ & $8 q 24$ & Translocations & TRA (14q11) & $6.1 \%$ & Unidentified & {$[44]$} \\
\hline $\begin{array}{c}\text { RUNX1 } \\
(A M L 1, C B F A 2, \\
P E B P 2 A B)\end{array}$ & $21 q 22.12$ & Mutations & - & $12.7 \%$ & Adverse & [17] \\
\hline \multirow{2}{*}{$\begin{array}{l}\text { ETV6 } \\
\text { (TEL) }\end{array}$} & \multirow{2}{*}{$12 q 13.2$} & Deletions & - & $5.6-6 \%$ & \multirow{2}{*}{ Unidentified } & {$[49,50]$} \\
\hline & & Translocations & $\begin{array}{c}A B L 1(9 \mathrm{q} 34) \\
\text { CTNNB1 } \\
(3 \mathrm{p} 22.1)\end{array}$ & $<1 \%$ & & {$[41]$} \\
\hline GATA3 & 10p14 & $\begin{array}{l}\text { Inactivating } \\
\text { mutations }\end{array}$ & - & $\begin{array}{c}9 \% \text { of paediatric } \\
\text { patients with } \\
\text { ETP-ALL }\end{array}$ & Adverse & {$[52,53]$} \\
\hline $\begin{array}{c}\text { LEF1 } \\
(T C F 10)\end{array}$ & $4 q 25$ & Deletions & - & $7-24.5 \%$ & Divided & {$[41,43,55-57]$} \\
\hline WT1 & $11 \mathrm{p} 13$ & Mutations & - & $9.1-13.2 \%$ & $\mathrm{~N} / \mathrm{A}$ & {$[41,58]$} \\
\hline
\end{tabular}


Table 1. Cont.

\begin{tabular}{|c|c|c|c|c|c|c|}
\hline Gene & Locus & Alterations & Partners gene & Incidence & Relevance & References \\
\hline NF1 & $17 q 11.2$ & Deletions & - & $7.4 \%$ & $\begin{array}{l}\text { adverse, } \\
\text { resistance to } \\
\text { treatment } \\
\text { induction }\end{array}$ & [43] \\
\hline \multirow{3}{*}{$\begin{array}{l}\text { IKZF1 } \\
\text { (LYF1) }\end{array}$} & \multirow{3}{*}{$7 \mathrm{p} 12.2$} & $\begin{array}{l}\text { Loss of its } \\
\text { function }\end{array}$ & \multirow{3}{*}{-} & $7.4 \%$ & \multirow{3}{*}{$\begin{array}{l}\text { Adverse, } \\
\text { especially in B } \\
\text { cell precursor } \\
\text { (BCP)-ALL }\end{array}$} & \multirow{3}{*}[41,43,49,63]{} \\
\hline & & Deletions & & $2.8 \%$ & & \\
\hline & & Mutations & & $2 \%$ & & \\
\hline $\begin{array}{c}P A X 5 \\
(B S A P)\end{array}$ & $9 \mathrm{p} 13.2$ & $\begin{array}{l}\text { Loss of its } \\
\text { function, } \\
\text { deletions and } \\
\text { mutations }\end{array}$ & - & $11-14 \%$ & Unidentified & {$[42,43,49]$} \\
\hline$I K Z F 2$ & $2 q 34$ & $\begin{array}{l}\text { loss of its } \\
\text { function, } \\
\text { deletions and } \\
\text { mutations }\end{array}$ & - & $3.4 \%$ & Unidentified & [63] \\
\hline
\end{tabular}

\footnotetext{
${ }^{1} \mathrm{OE}-$ overexpression, ${ }^{2}$ LE-low expression, ${ }^{3} \mathrm{~N} / \mathrm{A}$-no association.
}

The PAX5 (9p13.2) gene is responsible for B-cell-specific protein activator factor (BSAP) transcription. Its role has been described mainly in the pathogenesis of BCP-ALL. However, recent studies suggest that the loss of its function may also occur in T-ALL. PAX5 gene abnormalities occurred in 14\% of T-ALL children [42]. Olsson and Thakral obtained similar results, with alterations in PAX5 found in approximately $11 \%$ of childhood T-ALL cases. Both studies were conducted on a limited number of T-ALL patients $[43,49]$. The significance of loss of PAX5 function in paediatric T-ALL remains unknown.

\subsection{Signalling Pathway Regulators}

\subsubsection{NOTCH1 Pathway}

An often observed phenomenon in T-ALL patients is a mutation in NOTCH1 (9q34.3) and FBXW7 (4q31.3) genes. It is estimated that mutations in the NOTCH1 gene are the most common genetic abnormality observed in T-ALL (Table 2). Despite such frequent occurrences, it turned out to be a positive prognostic factor. The NOTCH1 gene is responsible for correct $\mathrm{T}$ cell differentiation. Mutations of this gene were observed in more than half of paediatric patients with T-ALL. The NOTCH1 gene is also activated by chromosomal rearrangement-translation (7;9)(q34:q34.3), which leads to the active form of NOTCH1 [68].

The FBXW7 gene is located on chromosome 4, and its inactivating mutation plays a role in oncogenic NOTCH1 path activation. The NOTCH1 gene also influences the degradation of MYC and cyclin E. Its mutation is observed with a frequency from about 10 to even $20 \%$ of T-ALL cases, depending on the study.

A study conducted by Liu et al. showed a correlation between mutations in the NOTCH1 and FBXW7 genes and the prognosis of T-ALL patients. The activating mutation in NOTCH1/FBXW7 genes was observed in $60.60 \%$, whereas NOTCH1 mutation affected $51.11 \%$ of patients, and for $F B X W 7$ gene it was $22.38 \%$ [68]. In 2017, a study on $264 \mathrm{~T}$ ALL children, mutations in NOTCH1 and FBXW7 genes were found in 74.6 and $23.9 \%$, respectively [41]. Patients with mutations in the NOTCH1 gene (with or without FBXW7 commutation) were characterized by longer 5-year OS and event-free survival (EFS) [68].

Patient samples were compared at the beginning of T-ALL disease and the moment of relapse. Mutation in NOTCH1 was observed with similar frequency in patients at the time of diagnosis as during relapse, in 66.7 and $72.7 \%$, respectively. However, much more often at the moment of primary diagnosis, mutations concerned FBXW7 (20.0\%), DNM2-19p13.2 (20.0\%), and PHF6 (20.0\%) genes. In contrast, NT5C2 10q24.32-q24.33 gene mutation (27.3\%) 
was observed among patients who relapsed. This mutation showed a link to the risk of relapse in the study [69].

The mutation of NOTCH1 in two out of three patients concerned the heterodimerization domain (HD), and in 31.4\% the -Pro-Gln-Ser-Thr- (PEST) domain. Moreover, almost $30 \%$ of patients had many NOTCH1 mutations [41]. NOTCH1 mutations involving the C-terminal sequence were observed (PEST). These were much more common in patients who had relapsed (58.3\%) than in those who had not relapsed (16.7\%) [69].

A study that included $\gamma$-secretase inhibitors (GSI) in the treatment was conducted, but it showed high toxicity and did not yield the expected results [70]. However, it was suggested that the administration of an antimalarial drug chloroquine (which also has an anti-NOTCH1 effect, but with a different mechanism) would cause synergy of action and increased sensitivity to GSI and improved GSI therapeutic effects [71].

\subsubsection{PI3-AKT-mTOR Pathway}

PTEN (10q23.31) is a tumour suppressor gene whose mutations are observed in numerous cancers [72]. Alterations in the PTEN gene were observed in $11-27 \%$ of paediatric patients with T-ALL [73]. The main causes of PTEN gene inactivation are monoallelic point mutations, gene removal, or microdeletions [73]. This gene encodes a protein that is the most important negative regulator of the PI3/AKT/mTOR pathway. The loss of PTEN gene function due to mutations and deletions leads to inhibition transformation of dephosphorylation phosphatidylinositol $(3,4,5)$ P3 (PIP3) to phosphatidylinositol $(4,5)$ P2 (PIP2). This results in over-activation of the PI3/AKT/mTOR path caused by excess PIP3 and increased AKT1 (serine-threonine protein kinase) activity. PI3/AKT/mTOR has a regulatory effect on proliferation, differentiation, metabolism, and cell apoptosis. Excessive activation of this oncogenic pathway causes intensification of cell metabolism and proliferation and decreased apoptosis, and is often observed in patients with T-ALL [56].

CNAs in PTEN, PI3K, and AKT were noticed in primary T-ALL, which may suggest their role in the pathogenesis of leukaemia [74]. In a study conducted by SzarzyńskaZawadzka et al., PTEN mutations and copy number variations in 162 paediatric patients with T-ALL diagnosis were analysed. Mutations and deletions were observed in 9 and $16 \%$ of patients, respectively. Coexistence of both deletion and mutation was observed in $8 \%$ of patients [72]. In a study conducted by Liu, PTEN mutation affected $14.0 \%$ of patients [41]. Similarly, Gutierrez et al. observed that PTEN deletions occurred in $8.7 \%$ of primary T-ALL patients. PI3/AKT/mTOR path activation may also occur as a result of PI3K or AKT mutation [74]. Lejman et al. observed CNAs in PI3K/mTOR pathway with a frequency of $23.26 \%$ in childhood T-ALL. Alterations in PTEN, AKT1 (14q32.33), and PIK3CD (1p36.22) genes occurred in 11.63, 6.98, and 4.65\%, respectively [42].

Patients with PTEN dysfunction were characterized by weaker response to prednisone treatment on day 8 after induction, and shorter 5-year ESF and higher risk of relapse compared to others with properly functioning PTEN genes [72]. Poorer outcome and response to treatment was observed only in the group with PTEN deletion [73]. The above correlation was not noticed in patients with only PTEN gene mutation. Moreover, the mutation of $A K T 1$ induced resistance to prednisone [56]. Another study confirmed that deletions in PTEN may contribute to treatment failure. However, this was not observed in the case of alterations in PTEN-PI3K-AKT [74].

MiR-19 has also been shown to inhibit the expression of PTEN. Additionally, the existence of an additional pathway of PI3K/Akt attenuation by PTEN using Ikaros $/ \mathrm{miR}-26 \mathrm{~b}$ axis was noted. It is worth mentioning that inactivation of PTEN increases the level of c-MYC expression by inhibiting its degradation by GS3K $\beta$ [73].

The above-mentioned data indicate the need to conduct clinical trials involving $A K T$, PI3K, and $m$ TOR inhibitors for targeted therapy. 


\subsubsection{JAK-STAT Pathway}

This pathway starts with the effect of IL-7 on its receptor, which leads to JAK1 (1p31.3) and JAK3 (19p13.11) phosphorylation. The next stage is the activation of STAT5 proteins, which regulate the transcription of genes responsible for antiapoptotic properties in the cell (BCL-2 BCL-XL MLC1) [1]. Therefore, constitutive activation of this pathway leads to uncontrolled proliferation of leukemic cells [56]. This path can be adjusted on several levels. The first one is activating IL-7R mutation, with a frequency of $6.8 \%$ [41]. The second is activating mutations in JAK1, JAK3, or STAT5B (17q21.2) [56]. JAK3 mutations occur in $7.6 \%$ of T-ALL patients [41]. Activating mutations of $J A K 1$ gene were observed more often in T-ALL as compared to JAK2 (9p24.1) in the BCP-ALL group. In patients with JAK gene mutation, more frequent co-mutations in the IKZF1 gene and CRLF2- Xp22.3 and Yp11.3 (CRFL2-r) rearrangements were observed [56].

Another JAK-STAT aberrant modulator is DNM2 inactivation, which leads to IL-7R overexpression on thymocytes [1]. In a study conducted by Liu et al., DNM2 mutation occurred in $11 \%$ of T-ALL paediatric patients [41]. It has been observed that in T-ALL patients, SH2B3 (12q24.12) mutations lead to aberrant activation of JAK2/STAT pathway [56]. It is worth mentioning that in $7 \%$ of patients with T-ALL diagnosis as a result of mutation and loss of PTPN2 function, the JAK-STAT pathway was activated. A study carried out by Follini showed that aberrant activation of the JAK-STAT pathway is associated with induction of leukemic cell resistance to steroid therapy [1]. Alcantara et al. identified deletion in the protein tyrosine phosphatase nonreceptor type 2 (PTPN2-18p11.21) tumour suppressor gene. This deletion occurred in $6 \%$ of paediatric patients. In $54 \%$, the deletion concerned both alleles, and in the remaining $46 \%$ of cases, it was monoallelic. An association was observed between the PTPN2 loss and co-occurrence of $\alpha \beta$ lineage and TLX1 deregulation. Significantly, more patients with PTPN2 deletion than PTPN2 wild-type T-ALL had other accompanying disorders: NUP214- $A B L$ gene fusion (21 vs. 7\%), IL7R/JAK-STAT (74 vs. $41 \%$ ), NOTCH1/FBXW7 (85 vs. $63 \%$ ), and PHF6 (95 vs. $41 \%$ ) mutations. Moreover, PTPN2 deletion is an indicator of better outcome and glucocorticoid response. Lower 5-year OS and higher cumulative incidence of relapse (CIR) were observed in patients without PTPN2 gene deletion compared to patients with a loss of PTPN2 function: 78 vs. $92 \%$ and 26 vs. $8 \%$, respectively [31].

A total of 178 paediatric patients undergoing AIEOP-BFM ALL 2009 protocol treatment were subjected to CRLF2 (Xp22.3) gene expression level analysis; $14.6 \%$ of them had increased gene expression. P2RY8/CRLF2 rearrangement was not observed in this group. In response to the question of whether increased CRLF2 gene expression is of prognostic significance, minimal residual disease (MRD) and prednisone response were analysed. Patients with low expression responded to treatment, and prednisone resistance was observed in 35\%. In contrast, glucocorticoid resistance was observed in 2 out of 3 patients with high CRLF2 expression. Among patients classified as high-risk based on MRD measured on the 15th day after the induction of treatment, as much as $62 \%$ had CRLF2 overexpression, compared to $23 \%$ of children with CRLF2 downregulation [75].

\subsubsection{RAS Pathway}

In the Ras signal, we distinguish three types of genes involved: NRAS (neuroblastoma Ras; 1p13.2), KRAS (Kirsten Ras; 12p12.1), and HRAS (Harvey Ras; 11p15.5). Interestingly, studies carried out on mouse models proved that co-occurrence of mutations of these genes with NOTCH1 and IL-7R mutations and inactivation of EZH2 may be responsible for leukaemia induction. ETP-ALL cases were characterized by more frequent occurrences of $\mathrm{N}-/ \mathrm{K}$-Ras mutation activation. Additionally, this disorder was associated with TLX1/TLX3+ and HOXA+ patients [76]. N-Ras gene mutation was observed with a frequency of $6.2 \%$ [57], $7.6 \%$ [41], 10.8\% [17], and 7\% [77] among patients with T-ALL. The frequency of K-Ras mutation was $2.1 \%$ [57], 5.9\% [17], and $11.4 \%$ [77]. These genes were more frequently mutated in patients with CDKN2B hypermethylation [17]. Additionally, Zhang and Richter-Pechańska suggested that it may be associated with relapse and glucocorticosteroid resistance [11,78]. 
Iacobucci et al. observed that Ras pathway mutations appeared during treatment and were dominant in secondary disease, and are related to high risk and poor outcome [9].

Table 2. Signalling pathway regulators in T-ALL.

\begin{tabular}{|c|c|c|c|c|c|}
\hline Gene & Locus & Alterations & Incidence & Relevance & References \\
\hline \multirow[t]{2}{*}{ NOTCH1 } & \multirow[t]{2}{*}{$9 q 34.3$} & $\begin{array}{l}\text { Activating } \\
\text { mutations }\end{array}$ & $51.1-74.6 \%$ & \multirow{2}{*}{$\begin{array}{l}\text { Favorable, targeted } \\
\text { therapy- }-\gamma \text {-secretase } \\
\text { inhibitors (GSI) }\end{array}$} & \multirow[t]{2}{*}[41,68]{} \\
\hline & & $\mathrm{t}(7 ; 9)(\mathrm{q} 34: \mathrm{q} 34.3)$ & $<1 \%$ & & \\
\hline FBXW7 & $4 q 31.3$ & $\begin{array}{l}\text { Inactivating } \\
\text { mutations }\end{array}$ & $22.4-23.9 \%$ & Unidentified & {$[41,68]$} \\
\hline \multirow{2}{*}{$\begin{array}{c}\text { PIK3CD } \\
(\text { PI3K-DELTA) }\end{array}$} & \multirow{2}{*}{$1 \mathrm{p} 36.22$} & Deletions & $4.65 \%$ & \multirow{2}{*}{$\begin{array}{c}\text { Unidentified, targeted } \\
\text { therapy-PI3K } \\
\text { inhibitors }\end{array}$} & [42] \\
\hline & & Mutations & $1.9 \%$ & & {$[41]$} \\
\hline$A K T$ & $14 q 32.33$ & Deletions & $6.98 \%$ & $\begin{array}{l}\text { Adverse, resistance to } \\
\text { steroids, targeted } \\
\text { therapy-AKT } \\
\text { inhibitors }\end{array}$ & {$[42,56]$} \\
\hline \multirow{2}{*}{ PTEN } & \multirow{2}{*}{$10 q 23.31$} & Mutations & $9-14 \%$ & \multirow{2}{*}{$\begin{array}{l}\text { Adverse, reduced } \\
\text { response to treatment }\end{array}$} & \multirow{2}{*}[41,42,72-74]{} \\
\hline & & Deletions & $8.7-16 \%$ & & \\
\hline DNM2 & $19 \mathrm{p} 13.2$ & $\begin{array}{c}\text { Inactivating } \\
\text { mutations }\end{array}$ & $11 \%$ & Unidentified & [41] \\
\hline$I L 7 R$ & $5 p 13$ & $\begin{array}{l}\text { Activating } \\
\text { mutations }\end{array}$ & $6.8 \%$ & Unidentified & {$[41]$} \\
\hline$J A K 3$ & 19p13.11 & $\begin{array}{l}\text { Activating } \\
\text { mutations }\end{array}$ & $7.6 \%$ & Unidentified & {$[41]$} \\
\hline PTPN2 & 18p11.21 & Deletions & $6 \%$ & $\begin{array}{l}\text { Favorable, good steroid } \\
\text { response }\end{array}$ & {$[31]$} \\
\hline CRLF2 & Xp22.3 and Yp11.3 & Overexpression & $14.6 \%$ & $\begin{array}{l}\text { Adverse, resistance to } \\
\text { steroids }\end{array}$ & [75] \\
\hline$N-R A S$ & 1p13.2 & $\begin{array}{l}\text { Activating } \\
\text { mutations }\end{array}$ & $6.2-10.8 \%$ & $\begin{array}{l}\text { Adverse, resistance to } \\
\text { steroids, associated with } \\
\text { relapse }\end{array}$ & {$[9,11,17,41,57,77,78]$} \\
\hline$K-R A S$ & $12 \mathrm{p} 12.1$ & $\begin{array}{l}\text { Activating } \\
\text { mutations }\end{array}$ & $2.1-11.4 \%$ & $\begin{array}{l}\text { Adverse, resistance to } \\
\text { steroids, associated with } \\
\text { relapse }\end{array}$ & {$[9,11,17,57,77,78]$} \\
\hline
\end{tabular}

\subsection{Cell Cycle Regulators}

$C D K N 2 A / 2 B$ (9p21.3) are among the most frequent CNAs occurring in paediatric patients with T-ALL (Table 3). Those genes, which belong to the INK family and lie on chromosome 9p21.3, demonstrate a tumour suppressive effect. CDKN2A/2B gene inactivation can proceed through deletion, mutation, or epigenetic silencing by hypermethylation of the promoter. The loss of function of $\mathrm{p} 15$ and p16 proteins encoded by these genes leads to uncontrolled proliferation of neoplastic cells [79].

CDKN2A/2B deletion is more common in T-ALL in comparison to BCP-ALL [79]. $C D K N 2 A$ deletion was observed in $66 \%$ of paediatric patients with T-ALL and CDKN2B in 55\% [11]. Moreover, this deletion occurred at higher frequency in patients with cortical T-ALL $(47 \%)$ than in those with ETP-ALL (3\%) [80]. It is important to mention that biallelic deletion was associated with all T-ALL cases compared to BCP-ALL cases, in which monoallelic deletion dominated. Hypermethylation is one way for inactivation to be observed more often in the CDKN2A gene [79]. In contrast, Jang observed that the main method of gene inactivation was deletion for $C D K N 2 A$, and both deletion and hypermethylation for CDKN2B [17]. 
The prognostic value of $C D K N 2 A / 2 B$ gene inactivation for progression of the disease and response to treatment is highly debatable, due to the small number of patients and the heterogeneous nature of T-ALL. Interestingly, patients with $C D K N 2 A / 2 B$ gene deletion were characterized by older age at diagnosis and a higher number of white blood cells (WBCs) in peripheral blood. These features are factors in poor ALL outcomes. It is also worth noting that deletion was correlated with lower event-free survival (ESF) versus lack of deletion, at 12.5 and $87.5 \%$, respectively. T-ALL patients with $C D K N 2 A / 2 B$ deletion had a significantly lower survival rate than patients without deletion [79]. As opposed to Agarwal, Genesca et al. reported that the prognosis for patients with $C D K N 2 A / 2 B$ inactivation was better. These T-ALL patients did not require intensification of therapy or marrow transplant. Better overall survival (OS) rates over 3 years were reported in patients with $C D K N 2 B$ deletion. This correlation was not observed in patients with $C D K N 2 A / A R F$ deletion [80].

In a study performed on 102 patients with T-ALL, Jang et al. observed the abovementioned gene deletions in 34.3\%. Similarly, to Agarwal, they found that the biallelic deletion was more often in the CDKN2A gene than in the CDKN2B gene, at 95.3 and $76.3 \%$, respectively. They also noted that methylation of both $C D K N 2 A / 2 B$ genes is more common in patients without deletion of these genes. Deactivation of $C D K N 2 B$ gene was mainly caused by epigenetic silencing by hypermethylation of promoter. Additionally, it is worth noting that $C D K N 2 B$ deletion was related to younger age at diagnosis, lower white blood cell (WBC) count and increased blast percentage, and more mature phenotype. In contrast, CDKN2B hypermethylation was observed in practically all ETP-ALL cases. Children with biallelic deletion or $>45 \%$ hypermethylation were compared with patients with monoallelic deletion and hypermethylation at levels below 45\%. The second group was characterized by better prognosis, longer EFS, and 3-year OS compared to the first group (59.1 vs. 35.9\%, 85.2 vs. $43.0 \%$, respectively) [17].

Inactivation of the cyclin-dependent kinase inhibitor $1 \mathrm{~B}$ gene, located on the chromosome 12 CDKN1B (12p13.1), is response for uncontrolled cell proliferation and has been observed in leukaemias [81]. In research conducted by Colomer-Lahiguer, deletion of this gene was found in about $12 \%$ of paediatric T-ALL patients. Patients with CDKN1B deletion were characterized by high HOXA subtype and less frequent coexistence of CNAs in $C D K N 2 A / 2 B$ genes. Moreover, the co-occurrence of CDKN1B deletion and MEF2C dysregulation was noted. Genetic changes involving $M E F 2 C$ were found in $54 \%$ of cases with $C D K N 1 B$ dysregulation, in comparison to $14 \%$ in patients with wild-type CDKN1B. Additionally, a link between poor response to steroids and $M E F 2 C$ dysregulation has been demonstrated [13].

Cycline D2 belongs to the group of proteins involved in the regulation of the cell cycle and is encoded by the CCND2 gene (12p13.32), located on chromosome 12, whose changes have been observed in numerous cancers [82]. A study by Clappier et al. compared the expression of CCND2 in a population of healthy thymus cells and cells of patients with T-ALL. It was observed that healthy cells had low CCND2 expression compared to cells in 3 translocated patients out of 89 T-ALL cases, characterized by massive overexpression of this gene. This discovery led to the suspicion that CCND2 overexpression in T-ALL cells has a role in T-ALL development [83]. 
Table 3. Cell cycle regulators in T-ALL.

\begin{tabular}{|c|c|c|c|c|c|}
\hline Gene & Locus & Alterations & Incidence & Relevance & References \\
\hline $\begin{array}{c}C D K N 2 A \\
(\mathrm{p} 16(\mathrm{INK} 4 \mathrm{~A}))\end{array}$ & 9 p21.3 & $\begin{array}{c}\text { Deletions, } \\
\text { mutations, } \\
\text { promoter } \\
\text { hypermethylation }\end{array}$ & $66 \%$ & Divided & {$[11,17,79,80]$} \\
\hline $\begin{array}{c}\text { CDKN2B } \\
(\mathrm{p} 15(\mathrm{INK} 4 \mathrm{~B}))\end{array}$ & 9 p21.3 & $\begin{array}{c}\text { Deletions, } \\
\text { mutations, } \\
\text { promoter } \\
\text { hypermethylation }\end{array}$ & $55 \%$ & Divided & {$[11,17,79,80]$} \\
\hline $\begin{array}{c}C D K N 1 B \\
(\mathrm{p} 27(\mathrm{KIP} 1))\end{array}$ & $12 \mathrm{p} 13.1$ & $\begin{array}{c}\text { Deletions; } \\
\text { cooccurrence with } \\
M E F 2 C \\
\text { dysregulation }\end{array}$ & $12 \%$ & $\begin{array}{l}\text { Adverse, reduced } \\
\text { response to } \\
\text { steroids }\end{array}$ & [13] \\
\hline CCND2 & $12 \mathrm{p} 13.32$ & Overexpression & $3.4 \%$ & Unidentified & [83] \\
\hline
\end{tabular}

\subsection{Kinase Signalling}

In recent years, the efficacy of tyrosine kinase inhibitors (TKIs) has been observed in patients with platelet derived growth factor $\mathrm{b}$ (PDGFRb) activation [84] (Table 4). As a result of this discovery, a new group of patients was described who showed gene expression similar to Ph-like ALL, but had no fusion between $B C R$ and $A B L 1$. Among this group, cases with PDGFRB (5q32) rearrangements were observed. EBF1-PDGFRB (5q33.3), which determined good response to ABL1 TKI, was described. Heilman et al. reported three consecutive partner genes, SATB1 (3p24.3), AGGF1 (5q13.3), and DOCK2 (5q35.1), which had PDGFRB rearrangements in T- and BCP-ALL patients [85]. Bielorai was the first to describe a paediatric T-ALL case of a patient with PDGFRB-R and $\mathrm{t}(5 ; 14)$ (q33;q32) who responded well to imatinib treatment [86]. In contrast, Zhang observed a PDGFRBC843G mutation in a Ph-like ALL patient, which conditioned resistance to ABL TKIs and sensitivity to the CHZ868 multitarget kinase inhibitor [87].

Table 4. Kinase signalling in T-ALL.

\begin{tabular}{|c|c|c|c|c|c|c|}
\hline Gene & Locus & Alterations & Partner Genes & Incidence & Relevance & References \\
\hline PDGFRb & $5 q 32$ & Rearrangements & $\begin{array}{l}\text { EBF1 (5q33.3), } \\
\text { SATB1 (3p24.3), } \\
\text { AGGF1 (5q13.3) } \\
\text { DOCK2 (5q35.1) }\end{array}$ & single cases & $\begin{array}{c}\text { Adverse, } \\
\text { tyrosine kinase } \\
\text { inhibitor (TKI) } \\
\text { treatment }\end{array}$ & {$[85,86]$} \\
\hline \multirow[b]{2}{*}{$A B L 1$} & \multirow[b]{2}{*}{$9 q 34.12$} & \multirow[b]{2}{*}{$\begin{array}{l}\text { Rearrangements, } \\
\text { amplifications }\end{array}$} & $\begin{array}{l}\text { NUP214 } \\
\text { (9q34.13) }\end{array}$ & $5-6 \%$ & & \\
\hline & & & $\begin{array}{c}\text { BCR (22q11.23), } \\
\text { ETV6 (12p13.2), } \\
\text { ZBTB16 } \\
(11 \mathrm{q} 23.2), \text { EML1 } \\
(14 \mathrm{q} 32.2)\end{array}$ & $<1 \%$ & $\begin{array}{l}\text { Adverse, TKI } \\
\text { treatment }\end{array}$ & {$[42,88,89]$} \\
\hline $\begin{array}{l}\text { FLT3 } \\
\text { (STK1) }\end{array}$ & $13 q 12.2$ & Mutations & - & $3.0-3.8 \%$ & $\mathrm{~N} / \mathrm{A}$ & {$[47,77]$} \\
\hline
\end{tabular}

ABL1 (9q34.12) fusion proteins were observed in $8 \%$ of T-ALL cases and were linked to leukemic survival and proliferation of cells, and provided sensitivity to tyrosine kinase inhibitors. Among all partner genes, NUP214 (9q34.13) is the most common and characteristic, and occurs in $6 \%$ of childhood T-ALL cases. Other genes, such as BCR (22q11.23), ETV6 (12p13.2), ZBTB16 (11q23.2), and EML1 (14q32.2), are found more frequently in other cancers and are rarely observed in T-ALL [88]. Amplification of the NUP214-ABL1 gene was observed in $5-6 \%$ and was linked to therapy failure and relapse [42]. BCR-ABL1 
fusion due to $\mathrm{t}(9 ; 22)(\mathrm{q} 34 ; \mathrm{q} 11.2)$ was observed in $9 \% \mathrm{Ph}+\mathrm{ALL}$ patients, but taking into consideration the whole ALL population, it was observed in only $0.3 \%$. Rearrangement between 9q34 and 12p13 was involved in ETV6-ABL1 fusion [88]. Chen et al. observed ZBTB16-ABL1 fusion in two cases. This rearrangement co-occurred with other genetic alterations, such as NOTCH1, PTEN, MYCN, and PIK3CD and ZEB2 mutations. Both cases were characterized by a very aggressive process. In an in vitro study, the activity of TKI on cells with ZBTB16-ABL1 and $B C R-A B L 1$ was checked, showing similar sensitivity to this therapy [89]. The extremely rare phenomenon of translocation $(9 ; 12)(\mathrm{q} 34 ; \mathrm{p} 13)$ leads to fusion between the EML1 and ABL1 genes. Hagemeijer observed EML1-ABL1 in only one patient with T-ALL [88]. The assessment of $A B L 1$ rearrangements is extremely important in the context of the possibility and reasonableness of using targeted therapy with TKI.

The FLT3 (13q12.2) gene regulates haematopoiesis and is responsible for the formation of tyrosine receptor class III kinase. The tyrosine kinase activation occurs as a result of internal duplication of the FLT3/ITD tandem, which is most frequently observed in TALL [18]. Mutations of this gene were observed in 3\% of patients with T-ALL [47]. FLT3 overexpression was observed more commonly in ETP-ALL cases [41]. Interestingly, this mutation was more common in BCP-ALL compared to T-ALL (7 vs. 3.8\%) [77]. Mutation of the FLT3 gene in acute myeloblastic leukaemia affects every third patient and has a proven negative prognosis [47]. In T-ALL, due to the rare occurrence of this gene aberration and the small size of the study group, no effect of FLT3 mutation on patients' prognosis was discovered.

\subsection{T-ALL Rearrangements}

SIL-TAL1 (1p32; 1p33) gene rearrangements in paediatric patients with T-ALL are observed with a 16-26\% frequency [90] (Table 5). In a study carried out on a group of 68 patients (26 paediatric), SIL-TAL1 gene fusion was observed in $38.5 \%$ of children. The group of patients with SIL-TAL1 gene fusion was characterized by younger age, higher WBC count at the time of diagnosis, a higher level of lactate dehydrogenase (LDH), and increased frequency of disseminated intravascular coagulation (DIC) and acute tumour lysis complications $[90,91]$. Therefore, the occurrence of this fusion was associated with worse prognosis. A study in a group of 101 children with T-ALL did not show any differences in minimal residual disease (MRD), 5-year EFS or relapse-free survival (RFS) between patients with and without the fusion. The possibility of worse response to remission induction therapy was observed because higher MRD was observed more often among patients with SIL-TAL1 gene rearrangements [92]. Additionally, in a study conducted by Ohki, a higher incidence of SIL-TAL1 fusion was observed in patients in the EGIL-IV and -III groups, 55 and 30\%, respectively. Interestingly, patients with and without fusion did not show any differences. However, in group IV, patients with SIL-TALI1 were characterized by higher ESF (90\%) in comparison to others without fusion (57.1\%) [8]. TAL1 gene deletion is a common abnormality, observed with a frequency of $25 \%$ of patients with T-ALL [65]. Wang et al. achieved similar results. SIL-TAL1 deletion occurred in every fifth patient with T-ALL [66]. Both Chen and Wang suggested that TAL-1 gene deletion detection may be useful in assessing MRD in T-ALL patients $[65,66]$. In another study, deletion of TAL1 was observed in 3 out of 39 patients under 18 years of age and was associated with a higher WBC count [67].

Acute leukaemia with a PICALM-MLLT10 fusion gene (originally called CALM-AF10) is generated by $\mathrm{t}(10 ; 11)(\mathrm{p} 12-13 ; \mathrm{q} 14-21)$ translocation, and has been very rarely reported in patients with T-ALL, at an overall rate of 10\%, including both adults and children [93]. The presence of PICALM-MLLT10 has been associated with a poor prognosis, and several studies included very few children with T-ALL [94]. Literature on the PICALM-MLLT10 issue is quite limited, and no definitive conclusions have been drawn on the incidence and prognostic impact of this fusion transcript among children with T-ALL. Nigro et al. reported that PICALM-MLLT10 fusion transcript occurs in 7\% of children with T-lineage ALL and is not associated with poorer outcomes for patients treated with contemporary intensive 
chemotherapy [93]. This issue requires a multinational study to enable a meaningful retrospective analysis.

SET-NUP214 (9q34.11) was identified as a novel recurrent fusion gene in T cell leukaemia by Van Vlierberghe at al. They showed that SET-NUP214 may contribute to T-ALL pathogenesis by inhibition of T cell maturation through the transcriptional activation of HOXA genes, often predicting a poor outcome for patients [95]. The fusion transcript may be regarded as a potential minimal residual disease marker for SET-NUP214-positive patients [96]. Interstitial deletion, which results in SET/NUP214 fusion, has been described in 6 of 40 children with del 9q34 region in a study conducted by Papenhausen at al. [97].

Table 5. T-ALL rearrangements.

\begin{tabular}{cccccc}
\hline Fusion & Locus & Alterations & Incidence & Relevance & References \\
\hline SIL-TAL1 & 1p32;1p33 & Rearrangements & $16-38.5 \%$ & Adverse & {$[8,90-92]$} \\
\hline $\begin{array}{c}\text { PICALM-MLLT10 } \\
(\text { CALM-AF10) }\end{array}$ & 11q14.2; 10p12.31 & $\begin{array}{c}\text { Rearrangements, } \\
\mathrm{t}(10 ; 11)(\mathrm{p} 12- \\
13 ; \mathrm{q} 14-21)\end{array}$ & $7 \%$ & Adverse/unidentified & {$[93,94]$} \\
\hline & & Rearrangements & $15 \%$ & $\begin{array}{c}\text { Unidentified; } \\
\text { potential minimal } \\
\text { residual disease } \\
\text { (MRD) marker }\end{array}$ \\
\hline
\end{tabular}

\subsection{Epigenetic Regulators}

The polycomb protein complex (PRC2) includes EZH2 (7q36.1), EED (11q14.2) or SUZ12 (17q11.2). Mutations inactivating these genes lead to the acquisition of cell resistance to mitochondrial apoptosis and the drugs for which this mechanism is the grip point. In the Ariës study, mutations in the PRC2 complex affected every five childhood T-ALL cases [98] (Table 6). Another study showed a lower incidence; mutations in the EZH2 and EED genes were found in $3.3 \%$ of patients [99]. High expression of EZH2, EED, and SUZ12 genes was observed in 75,60 , and $58.3 \%$ of patients in whom these genes were expressed. The remaining cases were characterized by low expression [100]. In addition, Schafer et al. observed that paediatric patients with T-ALL were characterized by a significantly higher incidence of hypermethylation of the $E Z H 2$ gene promoter compared to healthy cells [99]. It has been shown that patients with high expression of EZH2 and EED genes are less likely to achieve disease-free survival (DFS) [100]. On the other hand, the PRC2 mutation was closely related to poorer response to drug treatment, but no correlation between inactivation of the PRC2 complex and shorter OS was reported [98].

Table 6. Epigenetic regulators in T-ALL.

\begin{tabular}{|c|c|c|c|c|c|}
\hline Gene & Locus & Alterations & Incidence & Relevance & References \\
\hline $\begin{array}{c}\text { EZH2 } \\
(\text { KMT6A, } \\
\text { ENX1) }\end{array}$ & $7 q 36.1$ & $\begin{array}{l}\text { Inactivating } \\
\text { mutations } \\
\text { and promoter } \\
\text { hypermethy- } \\
\text { lation }\end{array}$ & \multirow[t]{2}{*}{$3.3 \%$ (adult) } & \multirow{2}{*}{$\begin{array}{c}\text { Adverse, less } \\
\text { opportunity } \\
\text { to obtain } \\
\text { disease-free } \\
\text { survival } \\
\text { (DFS) }\end{array}$} & \multirow[t]{2}{*}{ [100] } \\
\hline$E E D$ & 11q14.2 & $\begin{array}{l}\text { Inactivating } \\
\text { mutations }\end{array}$ & & & \\
\hline $\begin{array}{c}\text { SUZ12 } \\
\text { (JJAZ1) }\end{array}$ & $17 q 11.2$ & $\begin{array}{l}\text { Inactivating } \\
\text { mutations }\end{array}$ & $0-7.4 \%$ & Adverse & {$[43,57]$} \\
\hline
\end{tabular}

\subsection{Tumour Suppressors}

PHF6 (Xq26.2), located on the $\mathrm{X}$ chromosome, acts as a suppressor gene, and its deletion may be relevant in T-ALL development [42] (Table 7). The literature reports PHF6 mu- 
tation occurring in $14,26.7,16$, and $5.4 \%$ of patients with paediatric T-ALL $[42,91,101,102]$. In addition, PHF6 mutation is more prevalent in men $(32.0 \%)$ than women $(2.5 \%)$ [102]. In contrast, Wang did not observe differences in the occurrence of PHF6 alterations between genders. In his study, the frequency of PHF6 alterations in children with T-ALL was 5.4\% for mutations and $2.5 \%$ for deletions [91]. Alterations in the PHF6 gene were much more frequently observed in adult patients with T-ALL compared to children (38 vs. 16\%) [102]. A similar trend was observed by Wang (18.6 and 5.4\%, respectively) [91]. On the other hand, CNAs in PHF6 were not reported in cases with BCP-ALL [102]. The molecular genetic markers most frequently associated with PHF6 mutations were NOTCH1 mutations, SET-NUP214 rearrangements, and JAK1 mutations. It has been suggested that the PHF6 gene may be relevant in inducing resistance to steroids [42,103]. Wang compared patients with and without PHF6 mutations and did not observe any differences between OS and DFS [91].

Table 7. Tumour suppressors in T-ALL.

\begin{tabular}{|c|c|c|c|c|c|}
\hline Gene & Locus & Alterations & Incidence & Relevance & References \\
\hline \multirow{2}{*}{ PHF6 } & \multirow{2}{*}{$X q 26.2$} & Mutations & $5.4-26.7 \%$ & \multirow{2}{*}{$\begin{array}{c}\text { Adverse, } \\
\text { resistance to } \\
\text { steroids }\end{array}$} & {$[41,42,91,101-103]$} \\
\hline & & Deletions & $2.5 \%$ & & [91] \\
\hline TP53 & 17p13.1 & $\begin{array}{c}\text { Mutations } \\
\text { and promoter } \\
\text { hypermethy- } \\
\text { lation }\end{array}$ & $5 \%$ & $\begin{array}{l}\text { Adverse, } \\
\text { reduced } \\
\text { response to } \\
\text { treatment } \\
\text { and shorter } \\
\text { OS }\end{array}$ & [56] \\
\hline \multirow{2}{*}{$R B 1$} & \multirow{2}{*}{ 13q14.2 } & Mutations & $9.5 \%$ & \multirow[t]{2}{*}{ - } & [41] \\
\hline & & Deletions & $5.6-8.3 \%$ & & {$[49,64]$} \\
\hline
\end{tabular}

The role of the TP53 gene as a tumour suppressor in the pathogenesis of many cancers is well known. Under normal conditions, the level of TP53 (17p13.1) is low because it occurs mainly in inactive form associated with MDM2. However, when DNA is damaged, it is activated for repair. The levels of $M D M 2$ and $R B$ are regulated by the CDKN2A gene, therefore deactivation of $C D K N 2 A$, which is common in T-ALL patients, leads to TP53 and $R B$ pathway disturbances [56]. $R B$ alterations were observed in $9.5 \%$ of T-ALL patients [41]. Deregulation of TP53 also occurs through a mutation, whose involvement in T-ALL recurrence was shown by Richter-Pechańska et al. [11]. Additionally, the presence of the mutation was associated with a reduced response to treatment and shorter OS. The pathway of TP53 is also affected by hypermethylation of promoters and miRNA-126 and $-181 \mathrm{a}$, involved in gene expression [56].

Deletion of exons $13-17$ in the RB1 gene (13q14.2) is frequently observed in various types of tumours, including retinoblastoma, breast cancer, and osteosarcoma, and the presence of a potential hotspot for recombination in the region was predicted [104]. CNAs in $R B 1$, which have a negative impact on the cell cycle, were reported in $24.4 \%$ of T-ALL patients [42]. In contrast, much rarer occurrences were observed in a study conducted on 264 children and young adults, in which the frequency of $R B 1$ mutations was determined to be $9.5 \%$ [41]. Deletion containing the RB1 gene was reported in 2 of 36 childhood T cell ALL cases $(5.6 \%)$ by Olsson and in $8.3 \%(n=2)$ by Krzanowski $[49,64]$.

\subsection{Translation and RNA Stability}

Ribosomes are responsible for protein synthesis, which is necessary for the proliferation of leukemic cells. In paediatric patients diagnosed with T-ALL, anomalies were observed in genes encoding cytoplasmic ribosomal proteins L5, L10, L11, and L22, which are components of subunit 60S (Table 8). Every fifth child with T-ALL had mutations and deletions of RPL10 (Xq28), RPL5 (UL18; 1p22.1), and RPL22 (1p36.31) [105]. The most 
frequent mutation in paediatric patients, with a frequency of $6-8.2 \%$, was observed in gene encoding cytoplasmic ribosomal protein L10. Interestingly, it usually involved missense mutations at residue R98 (Arg98Ser) [106,107]. Mutation in RPL5 affects $1.6 \%$ of paediatric T-ALL patients. Leukemic cells with the current RPL10R98S mutation are characterized by overexpression of BCL2 protein, which prevents apoptosis. This discovery may allow the use of BCL-2 targeted therapies [107].

Table 8. Translation and RNA stability in T-ALL.

\begin{tabular}{cccccc}
\hline Gene & Locus & Alterations & Incidence & Relevance & References \\
\hline RPL5 & $1 \mathrm{p} 22$ & $\begin{array}{c}\text { Inactivating } \\
\text { mutations }\end{array}$ & $1.6 \%$ & $\begin{array}{c}\text { Unidentified } \\
\text { Unidentified; } \\
\text { BCL-2 } \\
\text { targeted } \\
\text { therapies }\end{array}$ & {$[106]$} \\
RPL10 & $\mathrm{Xq} 28$ & $\begin{array}{c}\text { Inactivating } \\
\text { mutations }\end{array}$ & $6-8.2 \%$ & unidentified & {$[106]$} \\
\hline
\end{tabular}

\section{Genetic Aberrations Involved in Relapse}

A study conducted by Richter-Pechanska on a group of 214 T-ALL patients showed several genes that may be responsible for disease relapse and are much more common in relapsed patients than original patients [11].

In a study conducted by Kunz et al., NT5C2 mutation was noted in two patients with primary disease, while it was observed in $38.5 \%(n=5)$ of relapsed patients [108]. Similar to the above-mentioned study, the most frequent mutation detected in patients with relapse was NT5C2 gene activation mutation, which was observed in $24 \%$. However, it was suggested that this does not initiate relapse, as this mutation was observed in $71 \%$ of patients before relapse [11]. Additionally, it has been shown that this mutation is related to cell resistance to chemotherapy (6-mercaptopurine and 6-thioguanine) [78,108].

The second occurrence, concerning $13.4 \%$ of patients with relapse, was TP53 aberration. This disorder was much less common in primary disease $(1.36 \%)$. It is worth mentioning that deletions or single nucleotide variants (SNVs) are often accompanied by other CNAs. Additionally, the coexistence of gene mutations supervising DNA integrity was observed, with TP53 and USP7 (16p13.2), and MSH6 (2p16.3), as factors of relapse and high mortality [11]. USP7 mutations were noticed in $11.7 \%$ of patients with T-ALL diagnosis [41].

Another three mutations showed a connection to relapse. Mutation of $R A S$ genes (KRAS and NRAS) was observed in eight patients with T-ALL relapse. It was interesting that as many as six of them died within 3 months after the relapse [11].

Mutation of the CNOT3 (19q13.42) gene with tumour suppressor function occurs with a frequency of $8 \%$ in adult patients with T-ALL. In Richter-Pechanska's study, all patients in whom CNOT3 mutation was observed died due to relapse. The same observation was noted for IL-7 receptor mutation [11].

Mutations and gene deletions were also observed in paediatric patients whose protein products were involved in changes in chromatin conformation: PHF6 and EZH2. In a study conducted by Liu in 2017, PHF6 was observed in $18.9 \%$ of paediatric patients with T-ALL. It is also worth mentioning a mutation of ribosomal protein gene involved in the RPL10 translation process, which was observed in $6.1 \%$ of children with T-ALL [41].

\section{Chromothripsis}

Chromothripsis, as an expression of chromosomal instability, leads to complex reconfigurations in a short time [109]. Multiple CNAs occur during a single event, and this can result in the loss of chromosome fragments encoding suppressor genes and the formation of fusion genes that are relevant for oncogenesis. Therefore, its occurrence is observed in 
many diseases and cancers, but not often in T-ALL [110]. Ratnaparkhe et al. showed that the genomic landscape of patients with ataxia telangiectasia and T-ALL differs from that of sporadic ALL with a much higher frequency of chromothriptic events. They detected a high frequency of chromothriptic events in these tumours, specifically on acrocentric chromosomes [111]. Lejman et al. described the case of a child with T-ALL with chromothripsis including chromosome 11 . The scientists suggested that this process is linked to worse prognosis. Further research is needed in this area [42].

\section{Conclusions}

The last decade and the development of innovative technologies such as next-generation sequencing (NGS) have made it possible to accurately characterize the genetic changes associated with leukaemia transformation. However, T-ALL in children remains a major challenge due to its heterogeneous course, rare occurrence, and high heterogeneity. The search for predictive genetic markers in T-ALL is ongoing, and will provide critical and relevant information not only on the classification of patients to the appropriate risk and treatment groups, but also on markers for the evaluation of minimal residual disease, risk of relapse, resistance to given chemotherapies, and as grip points for targeted therapies.

The characterization of molecular alterations with prognostic impact in T-ALL may be very helpful for early identification of patients at high risk of failure, for whom more intensive treatments, including allogeneic hematopoietic stem cell transplantation, may be considered.

Author Contributions: M.L. was responsible for the conception and design of the study. A.M. and J.Z. were responsible for the acquisition of the literature for the manuscript. A.M. and M.L. wrote the original draft of manuscript. J.K., M.L., and J.Z. reviewed and edited. J.K. and M.L. supervised the paper. All authors have read and agreed to the published version of the manuscript.

Funding: This research was funded by the National Centre for Research and Development, Poland (grant number: STRATEGMED3/304586/5/NCBR/2017).

Conflicts of Interest: The authors declare no conflict of interest.

$\begin{array}{ll}\text { Abbreviations } \\ \text { AKT1 } & \text { the serine-threonine protein kinase } \\ \text { ALL } & \text { acute lymphoblastic leukemia } \\ \text { BCP-ALL } & \text { B-cell precursor acute lymphoblastic leukemia } \\ \text { BSAP } & \text { B-cell-specific protein activator factor } \\ \text { CIR } & \text { cumulative incidence of relapse } \\ \text { CNAs } & \text { copy number alterations } \\ \text { DFR } & \text { disease free of recurrence } \\ \text { DIC } & \text { disseminated intravascular coagulation } \\ \text { DR } & \text { Downregulation } \\ \text { EGIL } & \text { The European Group for the Immunologic Classification } \\ \text { ESF } & \text { event-free survival } \\ \text { ETP-ALL } & \text { Early T-cell precursor ALL } \\ \text { GSI } & \gamma \text {-secretase inhibitors } \\ \text { HD } & \text { heterodimerization domain } \\ \text { JAK 1 } & \text { janus kinase } 1 \\ \text { LBL } & \text { acute lymphoblastic lymphoma } \\ \text { LDH } & \text { lactate dehydrogenase } \\ \text { MRD } & \text { minimal residual disease } \\ \text { NGS } & \text { new generation sequencing } \\ \text { OE } & \text { Overexpression } \\ \text { OS } & \text { overall survival } \\ & \end{array}$




$\begin{array}{ll}\text { PDGFRb } & \text { platelet dderived growth factor b } \\ \text { PEST } & \text { (-Pro-Gln-Ser-Thr-) domain. } \\ \text { PIP2 } & \text { phosphatidylinositol }(4,5) \text { P2 } \\ \text { PIP3 } & \text { phosphatidylinositol }(3,4,5) \text { P3 } \\ \text { PRC } & \text { polycomb group complex } \\ \text { RFS } & \text { relapse-free survival } \\ \text { SNV } & \text { single nucleotide variants } \\ \text { STAT5B } & \text { signal transducer and activator of transcription 5B } \\ \text { T-ALL } & \text { T-cell acute lymphoblastic leukemia } \\ \text { TCR } & \text { T cell antigen receptor } \\ \text { TKI } & \text { tyrosine kinase inhibitor } \\ \text { WBC } & \text { white blood cell }\end{array}$

\section{References}

1. Follini, E.; Marchesini, M.; Roti, G. Strategies to Overcome Resistance Mechanisms in T-Cell Acute Lymphoblastic Leukemia. Int. J. Mol. Sci. 2019, 20, 3021. [CrossRef] [PubMed]

2. Raetz, E.A.; Teachey, D.T. T-cell acute lymphoblastic leukemia. Hematology 2016, 2016, 580-588. [CrossRef]

3. Allen, A.; Sireci, A.; Colovai, A.; Pinkney, K.; Sulis, M.; Bhagat, G.; Alobeid, B. Early T-cell precursor leukemia/lymphoma in adults and children. Leuk. Res. 2013, 37, 1027-1034. [CrossRef]

4. Belver, L.; Ferrando, A. The genetics and mechanisms of T cell acute lymphoblastic leukaemia. Nat. Rev. Cancer 2016, 16, 494-507. [CrossRef] [PubMed]

5. Hefazi, M.; Litzow, M.R. Recent Advances in the Biology and Treatment of T Cell Acute Lymphoblastic Leukemia. Curr. Hematol. Malig. Rep. 2018, 13, 265-274. [CrossRef] [PubMed]

6. Chiaretti, S.; Zini, G.; Bassan, R. Diagnosis and Subclassification of Acute Lymphoblastic Leukemia. Mediterr. J. Hematol. Infect. Dis. 2014, 6, e2014073. [CrossRef] [PubMed]

7. Szczepański, T.; van der Velden, V.H.J.; van Dongen, J.J.M. Classification systems for acute and chronic leukemias. Best Pract. Res. Clin. Haematol. 2003, 16, 561-582. [CrossRef]

8. Ohki, K.; Takahashi, H.; Fukushima, T.; Nanmoku, T.; Kusano, S.; Mori, M.; Nakazawa, Y.; Yuza, Y.; Migita, M.; Okuno, H.; et al. Impact of immunophenotypic characteristics on genetic subgrouping in childhood acute lymphoblastic leukemia: Tokyo Children's Cancer Study Group ( TCCSG ) study L04-16. Genes Chromosom. Cancer 2020, 59, 551-561. [CrossRef]

9. Iacobucci, I.; Mullighan, C.G. Genetic Basis of Acute Lymphoblastic Leukemia. J. Clin. Oncol. 2017, 35, 975-983. [CrossRef]

10. Hömig-Hölzel, C.; Savola, S. Multiplex Ligation-dependent Probe Amplification (MLPA) in Tumor Diagnostics and Prognostics. Diagn. Mol. Pathol. 2012, 21, 189-206. [CrossRef]

11. Richter-Pechańska, P.; Kunz, J.B.; Hof, J.; Zimmermann, M.; Rausch, T.; Bandapalli, O.R.; Orlova, E.; Scapinello, G.; Sagi, J.C.; Stanulla, M.; et al. Identification of a genetically defined ultra-high-risk group in relapsed pediatric T-lymphoblastic leukemia. Blood Cancer J. 2017, 7, e523. [CrossRef] [PubMed]

12. Pastorczak, A.; Młynarski, W.; Szczepański, T. Prognostic and therapeutic implications of genetic aberrationsin childhood acute lymphoblastic leukemia. Hematologia 2011, 2, 43-50.

13. Colomer-Lahiguera, S.; Pisecker, M.; König, M.; Nebral, K.; Pickl, W.F.; Kauer, M.O.; Haas, O.A.; Ullmann, R.; Attarbaschi, A.; Dworzak, M.N.; et al. MEF2C-dysregulated pediatric T-cell acute lymphoblastic leukemia is associated with CDKN1B deletions and a poor response to glucocorticoid therapy. Leuk. Lymphoma 2017, 58, 2895-2904. [CrossRef] [PubMed]

14. Ghodousi, E.S.; Aberuyi, N.; Rahgozar, S. Simultaneous changes in expression levels of BAALC and miR-326: A novel prognostic biomarker for childhood ALL. Jpn. J. Clin. Oncol. 2020, 50, 671-678. [CrossRef] [PubMed]

15. Wang, X.; Zhang, H.; Chen, X. Drug resistance and combating drug resistance in cancer. Cancer Drug Resist. 2019, 2, 141-160. [CrossRef]

16. Drobna, M.; Szarzyńska-Zawadzka, B.; Dawidowska, M. T-cell acute lymphoblastic leukemia from miRNA perspective: Basic concepts, experimental approaches, and potential biomarkers. Blood Rev. 2018, 32, 457-472. [CrossRef]

17. Jang, W.; Park, J.; Kwon, A.; Choi, H.; Kim, J.; Lee, G.D.; Han, E.; Jekarl, D.W.; Chae, H.; Han, K.; et al. CDKN2B downregulation and other genetic characteristics in T-acute lymphoblastic leukemia. Exp. Mol. Med. 2019, 51, 1-15. [CrossRef]

18. Kraszewska, M.D.; Dawidowska, M.; Szczepański, T.; Witt, M. T-cell acute lymphoblastic leukaemia: Recent molecular biology findings. Br. J. Haematol. 2012, 156, 303-315. [CrossRef]

19. Kawashima-Goto, S.; Imamura, T.; Tomoyasu, C.; Yano, M.; Yoshida, H.; Fujiki, A.; Tamura, S.; Osone, S.; Ishida, H.; Morimoto, A.; et al. BCL2 Inhibitor (ABT-737): A Restorer of Prednisolone Sensitivity in Early T-Cell Precursor-Acute Lymphoblastic Leukemia with High MEF2C Expression? PLoS ONE 2015, 10, e0132926. [CrossRef]

20. Iqbal, N.; Sharma, A.; Raina, V.; Kumar, L.; Bakhshi, S.; Kumar, R.; Gajendra, S. Poor Response to Standard Chemotherapy in Early T-precursor (ETP)-ALL: A Subtype of T-ALL Associated with Unfavourable Outcome: A Brief Report. Indian J. Hematol. Blood Transfus. 2014, 30, 215-218. [CrossRef] 
21. Tran, T.; Krause, J. Early T-cell precursor acute lymphoblastic leukemia with KRAS and DNMT3A mutations and unexpected monosomy 7. Bayl. Univ. Med. Cent. Proc. 2018, 31, 511-513. [CrossRef] [PubMed]

22. Zhang, Y.; Qian, J.-J.; Zhou, Y.-L.; Huang, X.; Li, J.-H.; Li, X.-Y.; Li, C.-Y.; Wang, H.-P.; Lou, Y.-J.; Meng, H.-T.; et al. Comparison of Early T-Cell Precursor and Non-ETP Subtypes Among 122 Chinese Adults With Acute Lymphoblastic Leukemia. Front. Oncol. 2020, 10, 10. [CrossRef]

23. Zuurbier, L.; Gutierrez, A.; Mullighan, C.G.; Canté-Barrett, K.; Gevaert, A.O.; De Rooi, J.; Li, Y.; Smits, W.K.; Buijs-Gladdines, J.G.; Sonneveld, E.; et al. Immature MEF2C-dysregulated T-cell leukemia patients have an early T-cell precursor acute lymphoblastic leukemia gene signature and typically have non-rearranged T-cell receptors. Haematologica 2013, 99, 94-102. [CrossRef] [PubMed]

24. Noronha, E.P.; Marques, L.V.C.; Andrade, F.G.; Thuler, L.C.S.; Terra-Granado, E.; Pombo-De-Oliveira, M. The Profile of Immunophenotype and Genotype Aberrations in Subsets of Pediatric T-Cell Acute Lymphoblastic Leukemia. Front. Oncol. 2019, 9, 9. [CrossRef] [PubMed]

25. Jain, N.; Lamb, A.V.; O’Brien, S.; Ravandi, F.; Konopleva, M.; Jabbour, E.; Zuo, Z.; Jorgensen, J.; Lin, P.; Pierce, S.; et al. Early T-cell precursor acute lymphoblastic leukemia/lymphoma (ETP-ALL/LBL) in adolescents and adults: A high-risk subtype. Blood 2016, 127, 1863-1869. [CrossRef] [PubMed]

26. Kumar, A.; Drusbosky, L.M.; Meacham, A.; Turcotte, M.; Bhargav, P.; Vasista, S.; Usmani, S.; Pampana, A.; Basu, K.; Tyagi, A.; et al. Computational modeling of early T-cell precursor acute lymphoblastic leukemia (ETP-ALL) to identify personalized therapy using genomics. Leuk. Res. 2019, 78, 3-11. [CrossRef]

27. Vicente, C.; Schwab, C.; Broux, M.; Geerdens, E.; Degryse, S.; Demeyer, S.; Lahortiga, I.; Elliott, A.; Chilton, L.; La Starza, R.; et al. Targeted sequencing identifies associations between IL7R-JAK mutations and epigenetic modulators in T-cell acute lymphoblastic leukemia. Haematologica 2015, 100, 1301-1310. [CrossRef]

28. Kowalczyk, J.; Sandberg, A.A. A possible subgroup of ALL with 9p-. Cancer Genet. Cytogenet. 1983, 9, 383-385. [CrossRef]

29. La Starza, R.; Lettieri, A.; Pierini, V.; Nofrini, V.; Gorello, P.; Songia, S.; Crescenzi, B.; Kronnie, G.T.; Giordan, M.; Leszl, A.; et al. Linking genomic lesions with minimal residual disease improves prognostic stratification in children with T-cell acute lymphoblastic leukaemia. Leuk. Res. 2013, 37, 928-935. [CrossRef]

30. Haider, Z.; Larsson, P.; Landfors, M.; Köhn, L.; Schmiegelow, K.; Flægstad, T.; Kanerva, J.; Heyman, M.; Hultdin, M.; Degerman, S. An integrated transcriptome analysis in T-cell acute lymphoblastic leukemia links DNA methylation subgroups to dysregulated TAL1 and ANTP homeobox gene expression. Cancer Med. 2019, 8, 311-324. [CrossRef]

31. Alcantara, M.; Simonin, M.; Lhermitte, L.; Touzart, A.; Dourthe, M.E.; Latiri, M.; Grardel, N.; Cayuela, J.M.; Chalandon, Y.; Graux, C.; et al. Clinical and biological features of PTPN2-deleted adult and pediatric T-cell acute lymphoblastic leukemia. Blood Adv. 2019, 3, 1981-1988. [CrossRef] [PubMed]

32. Chiaretti, S.; Foà, R. T-cell acute lymphoblastic leukemia. Haematologica 2009, 94, 160-162. [CrossRef] [PubMed]

33. Bongiovanni, D.; Saccomani, V.; Piovan, E. Aberrant Signaling Pathways in T-Cell Acute Lymphoblastic Leukemia. Int. J. Mol. Sci. 2017, 18, 1904. [CrossRef] [PubMed]

34. Kees, U.R.; Heerema, N.A.; Kumar, R.; Watt, P.M.; Baker, D.L.; La, M.K.; Uckun, F.M.; Sather, H.N. Expression of HOX11 in childhood T-lineage acute lymphoblastic leukaemia can occur in the absence of cytogenetic aberration at 10q24: A study from the Children's Cancer Group (CCG). Leukemia 2003, 17, 887-893. [CrossRef] [PubMed]

35. Pombo-De-Oliveira, M.S.; Andrade, F.G.; Carvalho, E.G.; Da Silva, A.M.M.; Agareno, J.M.D.A.; Dorea, M.D.; Araujo, F.N.S.; Burlachini, L.M.; Curvello, C.; Cardoso, T.C.; et al. Early-age Acute Leukemia: Revisiting Two Decades of the Brazilian Collaborative Study Group. Arch. Med. Res. 2016, 47, 593-606. [CrossRef]

36. Peterson, J.F.; Baughn, L.B.; Pearce, K.E.; Williamson, C.M.; Demasi, J.C.B.; Olson, R.M.; Goble, T.A.; Meyer, R.G.; Greipp, P.T.; Ketterling, R.P. KMT2A (MLL) rearrangements observed in pediatric/young adult T-lymphoblastic leukemia/lymphoma: A 10-year review from a single cytogenetic laboratory. Genes Chromosom. Cancer 2018, 57, 541-546. [CrossRef]

37. Mansur, M.B.; Emerenciano, M.; Splendore, A.; Brewer, L.; Hassan, R.; Pombo-De-Oliveira, M.S.; Pombo-De-Oliveira, M.S. T-cell lymphoblastic leukemia in early childhood presents NOTCH1 mutations and MLL rearrangements. Leuk. Res. 2010, 34, 483-486. [CrossRef]

38. Matlawska-Wasowska, K.; Kang, H.; Devidas, M.; Wen, J.; Harvey, R.C.; Nickl, C.K.; Ness, S.A.; Rusch, M.; Li, Y.; Onozawa, M.; et al. MLL rearrangements impact outcome in HOXA-deregulated T-lineage acute lymphoblastic leukemia: A Children's Oncology Group Study. Leukemia 2016, 30, 1909-1912. [CrossRef]

39. Forgione, M.O.; McClure, B.J.; Eadie, L.N.; Yeung, D.T.; White, D.L. KMT2A rearranged acute lymphoblastic leukaemia: Unravelling the genomic complexity and heterogeneity of this high-risk disease. Cancer Lett. 2019, 469, 410-418. [CrossRef]

40. Kang, H.; Sharma, N.D.; Nickl, C.K.; Devidas, M.; Loh, M.L.; Hunger, S.P.; Dunsmore, K.P.; Winter, S.S.; Matlawska-Wasowska, K. Dysregulated transcriptional networks in KMT2A- and MLLT10-rearranged T-ALL. Biomark. Res. 2018, 6, 27. [CrossRef]

41. Liu, Y.; Easton, J.; Shao, Y.; Maciaszek, J.; Wang, Z.; Wilkinson, M.R.; McCastlain, K.; Edmonson, M.; Pounds, S.; Meenakshi, D.; et al. The genomic landscape of pediatric and young adult T-lineage acute lymphoblastic leukemia. Nat. Genet. 2017, 49, 1211-1218. [CrossRef] [PubMed]

42. Lejman, M.; Włodarczyk, M.; Styka, B.; Pastorczak, A.; Zawitkowska, J.; Taha, J.; Sędek, Ł.; Skonieczka, K.; Braun, M.; Haus, O.; et al. Advantages and Limitations of SNP Array in the Molecular Characterization of Pediatric T-Cell Acute Lymphoblastic Leukemia. Front. Oncol. 2020, 10, 1184. [CrossRef] [PubMed] 
43. Thakral, D.; Kaur, G.; Gupta, R.; Benard-Slagter, A.; Savola, S.; Kumar, I.; Anand, R.; Rani, L.; Verma, P.; Joshi, S.; et al. Rapid Identification of Key Copy Number Alterations in B- and T-Cell Acute Lymphoblastic Leukemia by Digital Multiplex Ligation-Dependent Probe Amplification. Front. Oncol. 2019, 9, 871. [CrossRef] [PubMed]

44. La Starza, R.; Borga, C.; Barba, G.; Pierini, V.; Schwab, C.; Matteucci, C.; Fernandez, A.G.L.; Leszl, A.; Cazzaniga, G.; Chiaretti, S.; et al. Genetic profile of T-cell acute lymphoblastic leukemias with MYC translocations. Blood 2014, 124, 3577-3582. [CrossRef]

45. Dorfman, D.M.; Morgan, E.A.; Pelton, A.; Unitt, C. T-cell transcription factor GATA-3 is an immunophenotypic marker of acute leukemias with T-cell differentiation. Hum. Pathol. 2017, 65, 166-174. [CrossRef]

46. Fattizzo, B.; Rosa, J.; Giannotta, J.A.; Baldini, L.; Fracchiolla, N. The Physiopathology of T- Cell Acute Lymphoblastic Leukemia: Focus on Molecular Aspects. Front. Oncol. 2020, 10, 273. [CrossRef]

47. Kraszewska, M.D.; Dawidowska, M.; Kosmalska, M.; Sedek, Ł.; Grzeszczak, W.; Kowalczyk, J.R.; Szczepański, T.; Witt, M.; Lejman, M.; Jacek Wachowiak, K.D.; et al. BCL11B, FLT3, NOTCH1 and FBXW7 mutation status in T-cell acute lymphoblastic leukemia patients. Blood Cells Mol. Dis. 2013, 50, 33-38. [CrossRef]

48. Gutierrez, A.; Kentsis, A.; Sanda, T.; Holmfeldt, L.; Chen, S.-C.; Zhang, J.; Protopopov, A.; Chin, L.; Dahlberg, S.E.; Neuberg, D.S.; et al. The BCL11B tumor suppressor is mutated across the major molecular subtypes of T-cell acute lymphoblastic leukemia. Blood 2011, 118, 4169-4173. [CrossRef]

49. Olsson, L.; Lundin-Ström, K.B.; Castor, A.; Behrendtz, M.; Biloglav, A.; Norén-Nyström, U.; Paulsson, K.; Johansson, B. Improved cytogenetic characterization and risk stratification of pediatric acute lymphoblastic leukemia using single nucleotide polymorphism array analysis: A single center experience of 296 cases. Genes Chromosom. Cancer 2018, 57, 604-607. [CrossRef]

50. Cavé, H.; Cacheux, V.; Raynaud, S.; Brunie, G.; Bakkus, M.; Cochaux, P.; Preudhomme, C.; Laï, J.L.; Vilmer, E.; Grandchamp, B. ETV6 is the target of chromosome 12p deletions in $\mathrm{t}(12 ; 21)$ childhood acute lymphocytic leukemia. Leukemia 1997, 11, 1459-1464. [CrossRef]

51. Ho, I.-C.; Tai, T.-S.; Pai, S.-Y. GATA3 and the T-cell lineage: Essential functions before and after T-helper-2-cell differentiation. Nat. Rev. Immunol. 2009, 9, 125-135. [CrossRef] [PubMed]

52. Fransecky, L.; Neumann, M.; Heesch, S.; Schlee, C.; Ortiz-Tanchez, J.; Heller, S.; Mössner, M.; Schwartz, S.; Mochmann, L.H.; Isaakidis, K.; et al. Silencing of GATA3 defines a novel stem cell-like subgroup of ETP-ALL. J. Hematol. Oncol. 2016,9 , 95. [CrossRef] [PubMed]

53. Zhang, H.; Liu, A.P.Y.; Devidas, M.; Lee, S.H.R.; Cao, X.; Pei, D.; Borowitz, M.; Wood, B.; Gastier-Foster, J.M.; Dai, Y.; et al. Association of GATA3 Polymorphisms With Minimal Residual Disease and Relapse Risk in Childhood Acute Lymphoblastic Leukemia. J. Natl. Cancer Inst. 2020. [CrossRef] [PubMed]

54. Van Genderen, C.; Okamura, R.M.; Farinas, I.; Quo, R.G.; Parslow, T.G.; Bruhn, L.; Grosschedl, R. Development of several organs that require inductive epithelial-mesenchymal interactions is impaired in LEF-1-deficient mice. Genes Dev. 1994, 8, $2691-2703$. [CrossRef] [PubMed]

55. Gutierrez, A.; Sanda, T.; Ma, W.; Zhang, J.; Grebliunaite, R.; Dahlberg, S.E.; Neuberg, N.; Protopopov, A.; Winter, S.S.; Larson, R.S.; et al. Inactivation of LEF1 in T-cell acute lymphoblastic leukemia. Blood 2010, 115, 2845-2851. [CrossRef]

56. Montaño, A.; Forero-Castro, M.; Marchena-Mendoza, D.; Benito, R.; Hernández-Rivas, J.M. New Challenges in Targeting Signaling Pathways in Acute Lymphoblastic Leukemia by NGS Approaches: An Update. Cancers 2018, 10, 110. [CrossRef]

57. Yeh, T.; Liang, D.-C.; Liu, H.-C.; Jaing, T.-H.; Chen, S.; Hou, J.-Y.; Yang, C.-P.; Huang, Y.-J.; Yao, H.-W.; Huang, T.-Y.; et al. Clinical and biological relevance of genetic alterations in pediatric T-cell acute lymphoblastic leukemia in Taiwan. Pediatr. Blood Cancer 2019, 66, e27496. [CrossRef]

58. Tosello, V.; Mansour, M.R.; Barnes, K.; Paganin, M.; Sulis, M.L.; Jenkinson, S.; Allen, C.; Gale, R.E.; Linch, D.C.; Palomero, T.; et al. WT1 mutations in T-ALL. Blood 2009, 114, 1038-1045. [CrossRef]

59. Trovó-Marqui, A.B.; Tajara, E.H. Neurofibromin: A general outlook. Clin. Genet. 2006, 70, 1-13. [CrossRef]

60. Squazzo, S.L.; O'Geen, H.; Komashko, V.M.; Krig, S.R.; Jin, V.X.; Jang, S.W.; Margueron, R.; Reinberg, D.; Green, R.; Farnham, P.J. Suz12 binds to silenced regions of the genome in a cell-type-specific manner. Genome Res. 2006, 16, 890-900. [CrossRef]

61. Yoshida, N.; Sakaguchi, H.; Muramatsu, H.; Okuno, Y.; Song, C.; Dovat, S.; Shimada, A.; Ozeki, M.; Ohnishi, H.; Teramoto, T.; et al. Germline IKAROS mutation associated with primary immunodeficiency that progressed to T-cell acute lymphoblastic leukemia. Leukemia 2017, 31, 1221-1223. [CrossRef] [PubMed]

62. Ding, Y.; Zhang, B.; Payne, J.L.; Song, C.; Ge, Z.; Gowda, C.; Iyer, S.; Dhanyamraju, P.K.; Dorsam, G.; Reeves, M.E.; et al. Ikaros tumor suppressor function includes induction of active enhancers and super-enhancers along with pioneering activity. Leukemia 2019, 33, 2720-2731. [CrossRef] [PubMed]

63. Narita, A.; Muramatsu, H.; Yoshida, N.; Sakaguchi, H.; Doisaki, S.; Hama, A.; Nakanishi, K.; Takahashi, Y.; Miyajima, Y.; Matsumoto, K.; et al. Genetic Events in Ikaros Gene Family (IKZF1 and IKZF2) in Pediatric T-Cell Lymphoblastic Leukemia/Lymphoma. Blood 2012, 120, 4622. [CrossRef]

64. Krzanowski, J.; Madzio, J.; Pastorczak, A.; Tracz, A.; Braun, M.; Tabarkiewicz, J.; Pluta, A.; Młynarski, W.; Zawlik, I. Selected miRNA levels are associated with IKZF1 microdeletions in pediatric acute lymphoblastic leukemia. Oncol. Lett. 2017, 14, 3853-3861. [CrossRef] [PubMed]

65. Chen, X.; Pan, Q.; Stow, P.; Behm, F.G.; Goorha, R.; Pui, C.-H.; Neale, G. Quantification of minimal residual disease in T-lineage acute lymphoblastic leukemia with the TAL-1 deletion using a standardized real-time PCR assay. Leukemia 2001, 15, 166-170. [CrossRef] 
66. Wang, L.; Zhang, L.-P.; Li, Z.-G.; Cheng, Y.-F.; Tian, K.-G.; Lu, A.-D. A tal-1 deletion as real-time quantitative polymerase chain reaction target for detection of minimal residual disease in T-lineage acute lymphoblastic leukemia. Zhonghua Er Ke Za Zhi= Chin. J. Pediatr. 2005, 43, 170-173.

67. Sudhakar, N.; Nirmala, K.; Rajalekshmy, K.R.; Rajkumar, T. Does TAL-1 deletion contribute to the high incidence of T-cell acute lymphoblastic leukemia in South Indian patients? Asian Pac. J. Cancer Prev. 2008, 9, 127-130.

68. Liu, R.-B.; Guo, J.-G.; Liu, T.-Z.; Guo, C.-C.; Fan, X.; Zhang, X.; Hu, W.-H.; Cai, X.-Y. Meta-analysis of the clinical characteristics and prognostic relevance of NOTCH1 and FBXW7 mutation in T-cell acute lymphoblastic leukemia. Oncotarget 2017, 8, 66360-66370. [CrossRef]

69. Kimura, S.; Seki, M.; Yoshida, K.; Shiraishi, Y.; Akiyama, M.; Koh, K.; Imamura, T.; Manabe, A.; Hayashi, Y.; Kobayashi, M.; et al. NOTCH 1 pathway activating mutations and clonal evolution in pediatric T-cell acute lymphoblastic leukemia. Cancer Sci. 2019, 110, 784-794. [CrossRef]

70. Milano, J.; McKay, J.; Dagenais, C.; Foster-Brown, L.; Pognan, F.; Gadient, R.; Jacobs, R.T.; Zacco, A.; Greenberg, B.D.; Ciaccio, P.J. Modulation of Notch Processing by $\gamma$-Secretase Inhibitors Causes Intestinal Goblet Cell Metaplasia and Induction of Genes Known to Specify Gut Secretory Lineage Differentiation. Toxicol. Sci. 2004, 82, 341-358. [CrossRef]

71. Hounjet, J.; Habets, R.; Schaaf, M.B.; Hendrickx, T.C.; Barbeau, L.M.O.; Yahyanejad, S.; Rouschop, K.M.; Groot, A.J.; Vooijs, M.A.G.G. The anti-malarial drug chloroquine sensitizes oncogenic NOTCH1 driven human T-ALL to $\gamma$-secretase inhibition. Oncogene 2019, 38, 5457-5468. [CrossRef] [PubMed]

72. Szarzyńska-Zawadzka, B.; Kunz, J.B.; Sędek, Ł.; Kosmalska, M.; Zdon, K.; Biecek, P.; Bandapalli, O.R.; Kraszewska-Hamilton, M.; Jaksik, R.; Drobna, M.; et al. PTEN abnormalities predict poor outcome in children with T-cell acute lymphoblastic leukemia treated according to ALL IC-BFM protocols. Am. J. Hematol. 2019, 94, E93-E96. [CrossRef] [PubMed]

73. Martelli, A.M.; Paganelli, F.; Fazio, A.; Bazzichetto, C.; Conciatori, F.; McCubrey, J.A. The Key Roles of PTEN in T-Cell Acute Lymphoblastic Leukemia Development, Progression, and Therapeutic Response. Cancers 2019, 11, 629. [CrossRef] [PubMed]

74. Gutierrez, A.; Sanda, T.; Grebliunaite, R.; Carracedo, A.; Salmena, L.; Ahn, Y.; Dahlberg, S.; Neuberg, D.; Moreau, L.A.; Winter, S.S.; et al. High frequency of PTEN, PI3K, and AKT abnormalities in T-cell acute lymphoblastic leukemia. Blood 2009, 114, 647-650. [CrossRef]

75. Schmäh, J.; Fedders, B.; Panzer-Grümayer, R.; Fischer, S.; Zimmermann, M.; Dagdan, E.; Bens, S.; Schewe, D.; Moericke, A.; Alten, J.; et al. Molecular characterization of acute lymphoblastic leukemia with high CRLF2 gene expression in childhood. Pediatr. Blood Cancer 2017, 64, e26539. [CrossRef]

76. Evangelisti, C.; Chiarini, F.; McCubrey, J.A.; Martelli, A.M. Therapeutic Targeting of mTOR in T-Cell Acute Lymphoblastic Leukemia: An Update. Int. J. Mol. Sci. 2018, 19, 1878. [CrossRef]

77. Zhang, H.; Wang, H.; Qian, X.; Gao, S.; Xia, J.; Liu, J.; Cheng, Y.; Man, J.; Zhai, X. Genetic mutational analysis of pediatric acute lymphoblastic leukemia from a single center in China using exon sequencing. BMC Cancer 2020, 20, 1-11. [CrossRef]

78. Zhang, H.-H.; Wang, H.-S.; Qian, X.-W.; Fan, C.-Q.; Li, J.; Miao, H.; Zhu, X.-H.; Yu, Y.; Meng, J.-H.; Cao, P.; et al. Genetic variants and clinical significance of pediatric acute lymphoblastic leukemia. Ann. Transl. Med. 2019, 7, 296. [CrossRef]

79. Agarwal, M.; Bakhshi, S.; Dwivedi, S.N.; Kabra, M.; Shukla, R.; Seth, R. Cyclin dependent kinase inhibitor 2A/B gene deletions are markers of poor prognosis in Indian children with acute lymphoblastic leukemia. Pediatr. Blood Cancer 2018, 65, e27001. [CrossRef]

80. Genesca, E.; Lazarenkov, A.; Morgades, M.; Berbis, G.; Ruíz-Xivillé, N.; Gómez-Marzo, P.; Ribera, J.; Juncà, J.; Gonzalez-Perez, A.; Mercadal, S.; et al. Frequency and clinical impact of CDKN2A/ARF/CDKN2B gene deletions as assessed by in-depth genetic analyses in adult $\mathrm{T}$ cell acute lymphoblastic leukemia. J. Hematol. Oncol. 2018, 11, 1-4. [CrossRef]

81. Marinoni, I.; Pellegata, N.S. p27kip1: A New Multiple Endocrine Neoplasia Gene? Neuroendocrinology 2011, 93, 19-28. [CrossRef] [PubMed]

82. Hung, C.-S.; Wang, S.-C.; Yen, Y.-T.; Lee, T.-H.; Wen, W.-C.; Lin, R.-K. Hypermethylation of CCND2 in Lung and Breast Cancer Is a Potential Biomarker and Drug Target. Int. J. Mol. Sci. 2018, 19, 3096. [CrossRef] [PubMed]

83. Clappier, E.; Cuccuini, W.; Cayuela, J.-M.; Vecchione, D.; Baruchel, A.; Dombret, H.; Sigaux, F.; Soulier, J. Cyclin D2 dysregulation by chromosomal translocations to TCR loci in T-cell acute lymphoblastic leukemias. Leukemia 2005, 20, 82-86. [CrossRef] [PubMed]

84. Zabriskie, M.S.; Antelope, O.; Verma, A.R.; Draper, L.R.; Eide, C.A.; Pomicter, A.D.; Tran, T.H.; Druker, B.J.; Tyner, J.W.; Miles, R.R.; et al. A novel AGGF1-PDGFR $\beta$ fusion in pediatric T-cell acute lymphoblastic leukemia. Haematologica 2018, 103, 87-91. [CrossRef] [PubMed]

85. Heilmann, A.M.; Schrock, A.B.; He, J.; Nahas, M.; Curran, K.; Shukla, N.; Cramer, S.; Draper, L.; Verma, A.; Erlich, R.; et al. Novel PDGFRB fusions in childhood B- and T-acute lymphoblastic leukemia. Leukemia 2017, 31, 1989-1992. [CrossRef]

86. Bielorai, B.; Leitner, M.; Goldstein, G.; Mehrian-Shai, R.; Trakhtenbrot, L.; Fisher, T.; Marcu, V.; Yalon, M.; Schiby, G.; Barel, O.; et al. Sustained Response to Imatinib in a Pediatric Patient with Concurrent Myeloproliferative Disease and Lymphoblastic Lymphoma Associated with a CCDC88C-PDGFRB Fusion Gene. Acta Haematol. 2019, 141, 119-127. [CrossRef]

87. Zhang, Y.; Gao, Y.; Zhang, H.; Zhang, J.; He, F.; Hnízda, A.; Qian, M.; Liu, X.; Gocho, Y.; Pui, C.-H.; et al. PDGFRB mutation and tyrosine kinase inhibitor resistance in Ph-like acute lymphoblastic leukemia. Blood 2018, 131, 2256-2261. [CrossRef]

88. Hagemeijer, A.; Graux, C. ABLI rearrangements in T-cell acute lymphoblastic leukemia. Genes Chromosom. Cancer 2010, 49, 299-308. 
89. Chen, B.; Jiang, L.; Zhong, M.-L.; Li, J.-F.; Li, B.-S.; Peng, L.-J.; Dai, Y.-T.; Cui, B.-W.; Yan, T.-Q.; Zhang, W.-N.; et al. Identification of fusion genes and characterization of transcriptome features in T-cell acute lymphoblastic leukemia. Proc. Natl. Acad. Sci. USA 2017, 115, 373-378. [CrossRef]

90. Zhao, X.; Hong, Y.; Qin, Y.; Xu, Y.; Chang, Y.-J.; Wang, Y.; Zhang, X.; Xu, L.; Xiao-Jun, H. The clinical significance of monitoring the expression of theSIL-TAL1fusion gene in T-cell acute lymphoblastic leukemia after allogeneic hematopoietic stem cell transplantation. Int. J. Lab. Hematol. 2017, 39, 613-619. [CrossRef]

91. Wang, Q.; Wu, L.-L.; Dai, H.; Ping, N.-N.; Wu, C.-X.; Pan, J.; Cen, J.-N.; Qiu, H.; Chen, S. Correlation between expression of SIL-TAL1 fusion gene and deletion of 6q in T-cell acute lymphoblastic leukemia. Zhongguo Shi Yan Xue Ye Xue Za Zhi 2014, 22, 1508-1513. [PubMed]

92. Liu, X.; Li, W.-J.; Zhao, X.-X.; Gao, C.; Zhao, W.; Jiang, J.; Zhang, R.-D.; Xie, J.; Shi, H.-W.; Wang, B.; et al. Clinical Characteristics and Treatment Efficacy of Children with SIL/TAL1 Positive T-Cell Acute Lymphoblastic Leukemia. Zhongguo Shi Yan Xue Ye Xue Za Zhi 2016, 24, 681-686. [PubMed]

93. Nigro, L.L.; Mirabile, E.; Tumino, M.; Caserta, C.; Cazzaniga, G.; Rizzari, C.; Silvestri, D.; Buldini, B.; Barisone, E.; Casale, F.; et al . Detection of PICALM-MLLT10 (CALM-AF10) and outcome in children with T-lineage acute lymphoblastic leukemia. Leukemia 2013, 27, 2419-2421. [CrossRef] [PubMed]

94. Caudell, D.; Aplan, P.D. The role of CALM-AF10 gene fusion in acute leukemia. Leukemia 2007, 22, 678-685. [CrossRef]

95. Van Vlierberghe, P.; Van Grotel, M.; Tchinda, J.; Lee, C.; Beverloo, H.B.; Van Der Spek, P.J.; Stubbs, A.; Cools, J.; Nagata, K.; Fornerod, M.; et al. The recurrent SET-NUP214 fusion as a new HOXA activation mechanism in pediatric T-cell acute lymphoblastic leukemia. Blood 2008, 111, 4668-4680. [CrossRef]

96. Zhou, M.-H.; Yang, Q.-M. NUP214 fusion genes in acute leukemia (Review). Oncol. Lett. 2014, 8, 959-962. [CrossRef]

97. Papenhausen, P.; Kelly, C.A.; Zhang, Z.; Tepperberg, J.; Burnside, R.D.; Schwartz, S. Multidisciplinary analysis of pediatric T-ALL: 9q34 gene fusions. Cancer Genet. 2018, 1-13. [CrossRef]

98. Ariës, I.M.; Bodaar, K.; Karim, S.A.; Chonghaile, T.n.; Hinze, L.; Burns, M.A.; Pfirrmann, M.; Degar, J.; Landrigan, J.T.; Balbach, S.; et al. PRC2 loss induces chemoresistance by repressing apoptosis in T cell acute lymphoblastic leukemia. J. Exp. Med. 2018, 215, 3094-3114. [CrossRef]

99. Schäfer, V.; Ernst, J.; Rinke, J.; Winkelmann, N.; Beck, J.F.; Hochhaus, A.; Gruhn, B.; Ernst, T. EZH2 mutations and promoter hypermethylation in childhood acute lymphoblastic leukemia. J. Cancer Res. Clin. Oncol. 2016, 142, 1641-1650. [CrossRef]

100. D'Angelo, V.; Iannotta, A.; Ramaglia, M.; Lombardi, A.; Zarone, M.R.; Desiderio, V.; Affinita, M.C.; Pecoraro, G.; Di Martino, M.; Indolfi, P.; et al. EZH2 is increased in paediatric T-cell acute lymphoblastic leukemia and is a suitable molecular target in combination treatment approaches. J. Exp. Clin. Cancer Res. 2015, 34, 1-13. [CrossRef]

101. Spinella, J.-F.; Cassart, P.; Richer, C.; Saillour, V.; Ouimet, M.; Langlois, S.; St-Onge, P.; Sontag, T.; Healy, J.; Minden, M.D.; et al. Genomic characterization of pediatric T-cell acute lymphoblastic leukemia reveals novel recurrent driver mutations. Oncotarget 2016, 7, 65485-65503. [CrossRef] [PubMed]

102. Van Vlierberghe, P.; Palomero, T.; Khiabanian, H.; Van Der Meulen, J.; Castillo, M.; Van Roy, N.; De Moerloose, B.; Philippé, J.; González-García, S.; Toribio, M.L.; et al. PHF6 mutations in T-cell acute lymphoblastic leukemia. Nat. Genet. 2010, 42, 338-342. [CrossRef] [PubMed]

103. Xiang, J.; Wang, G.; Xia, T.; Chen, Z. The depletion of PHF6 decreases the drug sensitivity of T-cell acute lymphoblastic leukemia to prednisolone. Biomed. Pharmacother. 2019, 109, 2210-2217. [CrossRef] [PubMed]

104. Hong, F.D.; Huang, H.J.; To, H.; Young, L.J.; Oro, A.; Bookstein, R.; Lee, E.Y.; Lee, W.H. Structure of the human retinoblastoma gene. Proc. Natl. Acad. Sci. USA 1989, 86, 5502-5506. [CrossRef]

105. Hofman, I.; Patchett, S.; Van Duin, M.; Geerdens, E.; Verbeeck, J.; Michaux, L.; Delforge, M.; Sonneveld, P.; Johnson, A.W.; De Keersmaecker, K. Low frequency mutations in ribosomal proteins RPL10 and RPL5 in multiple myeloma. Haematologica 2017, 102, e317-e320. [CrossRef]

106. De Keersmaecker, K.; Atak, Z.K.; Li, N.; Vicente, C.; Patchett, S.; Girardi, T.; Gianfelici, V.; Geerdens, E.; Clappier, E.; Porcu, M.; et al. Exome sequencing identifies mutation in CNOT3 and ribosomal genes RPL5 and RPL10 in T-cell acute lymphoblastic leukemia. Nat. Genet. 2013, 45, 186-190. [CrossRef]

107. Kampen, K.R.; Sulima, S.O.; Verbelen, B.; Girardi, T.; Vereecke, S.; Rinaldi, G.; Verbeeck, J.; De Beeck, J.O.; Uyttebroeck, A.; Meijerink, J.P.P.; et al. The ribosomal RPL10 R98S mutation drives IRES-dependent BCL-2 translation in T-ALL. Leukemia 2018, 33, 319-332. [CrossRef]

108. Kunz, J.B.; Rausch, T.; Bandapalli, O.R.; Eilers, J.; Pechanska, P.; Schuessele, S.; Assenov, Y.; Stütz, A.M.; Kirschner-Schwabe, R.; Hof, J.; et al. Pediatric T-cell lymphoblastic leukemia evolves into relapse by clonal selection, acquisition of mutations and promoter hypomethylation. Haematologica 2015, 100, 1442-1450. [CrossRef]

109. Cortés-Ciriano, I.; Lee, J.J.-K.; Xi, R.; Jain, D.; Jung, Y.L.; Yang, L.; Gordenin, D.; Klimczak, L.J.; Zhang, C.-Z.; Pellman, D.S.; et al. Comprehensive analysis of chromothripsis in 2,658 human cancers using whole-genome sequencing. Nat. Genet. 2020, 52, 331-341. [CrossRef]

110. Karrman, K.; Johansson, B. Pediatric T-cell acute lymphoblastic leukemia. Genes Chromosom. Cancer 2017, 56, 89-116. [CrossRef]

111. Ratnaparkhe, M.; Hlevnjak, M.; Kolb, T.; Jauch, A.; Maass, K.K.; Devens, F.; Rode, A.; Hovestadt, V.; Korshunov, A.; Pastorczak, A.; et al. Genomic profiling of Acute lymphoblastic leukemia in ataxia telangiectasia patients reveals tight link between ATM mutations and chromothripsis. Leukemia 2017, 31, 2048-2056. [CrossRef] [PubMed] 